\title{
The Efficacy of Assisted Reproduction in Women with a Wide Spectrum of Chronic Diseases - A Review
}

\author{
Bente Mertz Nørgård (iD) ${ }^{1,2}$ \\ Laura Catalini (iD) 3,4 \\ Line Riis Jølving ${ }^{1,2}$ \\ Michael Due Larsen (iD) ${ }^{1,5}$ \\ Sonia Friedman 1,6 \\ Jens Fedder iD $^{3,4}$ \\ 'Center for Clinical Epidemiology, \\ Odense University Hospital, Odense, \\ Denmark; ${ }^{2}$ Research Unit of Clinical \\ Epidemiology, Department of Clinical \\ Research, University of Southern \\ Denmark, Odense, Denmark; ${ }^{3}$ Centre of \\ Andrology and Fertility Clinic, Odense \\ University Hospital, Odense, Denmark; \\ ${ }^{4}$ Research Unit of Gynecology and \\ Obstetrics, Department of Clinical \\ Research, University of Southern \\ Denmark, Odense, Denmark; \\ ${ }^{5}$ Department of Clinical and Molecular \\ Medicine, Norwegian University of \\ Science and Technology, Trondheim, \\ Norway; ${ }^{6}$ Center for Crohn's and Colitis, \\ Brigham and Women's Hospital, Harvard \\ Medical School, Boston, \\ Massachusetts, USA
}

\begin{abstract}
Assisted reproductive technology (ART) treatments in women with underlying chronic diseases have become increasingly frequent. The objective of this review is to provide an overview of the literature examining the chance of having a live born child after ART in women with chronic diseases, compared to other women receiving ART. We focused on some of the most prevalent chronic diseases in women during their reproductive years, ie ulcerative colitis, Crohn's disease, rheumatoid arthritis, multiple sclerosis, epilepsy, hyperthyroidism, hypothyroidism, and diabetes mellitus. Secondly, we studied the chance of successful implantation. The literature search was performed in the database Pubmed.gov. including all studies published before October 2020. Title and abstracts of 58 papers were reviewed, 37 papers were excluded and other 8 studies were excluded after full-text evaluation. Only 13 papers were eligible for review. Results indicate that women with ulcerative colitis, Crohn's disease, rheumatoid arthritis, hyperthyroidism, and diabetes mellitus type 2 might have problems with low implantation rate or early embryo development during ART. On the contrary, the few studies on women with hypothyroidism, diabetes mellitus type 1 , and epilepsy suggest an equivalent chance of a live birth compared to other women undergoing ART. A possible explanation behind these differences could reside in the diseasespecific dysregulation of the innate or adaptive immune system. To our knowledge, this is the first review on ART in women with chronic diseases, and it has disclosed that the evidence in this area is indeed sparse. We encourage others to examine live birth after ART in women with chronic diseases.
\end{abstract}

Keywords: assisted reproductive technology, inflammatory bowel diseases, rheumatoid arthritis, multiple sclerosis, epilepsy, thyroid disease, diabetes mellitus

\section{Introduction}

Having a child is one of the most important life events during adulthood, but the ability to conceive naturally is often not a matter of course. In the general population in Denmark, up to $16 \%$ of all women have problems with infertility, and when combining non-achievement of a first and/or a subsequent pregnancy, the infertility proportion reaches $24.2 \%{ }^{1}$ Seeking help from assisted reproductive technology (ART) is becoming common, and ART-conceived children represent $0.5-5 \%$ of the national birth cohorts in Europe. ${ }^{2-5}$ Patients starting the process of ART treatment expect to have information about their potential for a successful live birth. An increasing number of women who initiate ART treatment will have underlying chronic diseases and a recent Danish study of 1,362,200 childbirths demonstrated

\footnotetext{
Correspondence: Bente Mertz Nørgård Center for Clinical Epidemiology, Odense University Hospital, Kløvervænget 30 Entrance 216, Odense C, DK-5000,

Odense, Denmark

Tel +45 21333258

Email bente.noergaard@rsyd.dk
} 
that the prevalence of maternal chronic diseases during the reproductive years increased from $3.71 \%$ in 1989 to $15.76 \%$ in $2013 .{ }^{6}$ Because of an increasing prevalence of maternal chronic diseases, requests to initiate ART are more and more frequent in this population and clinicians can foresee having to answer an increasing number of questions related to ART. The objective of this review is to provide an overview of the literature examining the efficacy of ART in women with chronic diseases, compared to other women receiving ART.

Several overall aspects must be considered when examining the efficacy of ART, including which analytic approach to use (per cycle analyses or per woman analyses), and which outcome might be most appropriate (chance of a biochemical pregnancy, and/or a clinical pregnancy and/or a live born child). From a patient perspective, the ultimate goal for women seeking ART is to have a live born healthy child, and therefore, the focus in this review was to study the chance of having a live born child after embryo transfer. Secondly, we focused on two other outcomes, a biochemical pregnancy (positive pregnancy test, ie positive human chorionic gonadotropin (hCG) at 14-16 days after embryo transfer) and a clinical pregnancy (ie positive ultrasound examination 7-8 weeks after embryo transfer).

In this review, we did not include all possible chronic maternal underlying diseases. The research area on the efficacy of ART in women with different chronic diseases is still new, and the amount of literature is limited. In this review, we focused on women with frequent chronic diseases during the reproductive years, and we had a special interest in diseases with a possible pathophysiology related to autoimmunity and inflammation (Figure 1). Therefore, we included women with underlying diseases of ulcerative colitis, Crohn's disease, rheumatoid arthritis, multiple sclerosis, epilepsy, thyroid disease, and diabetes mellitus. Based on women with these diseases, we thus aimed to provide an overview of the literature examining the chance of a live born child after ART, compared to other women in the general population receiving ART.

\section{Materials and Methods}

\section{Search Strategy}

We performed our search based on the database PubMed.gov. All studies published before October 2020 were included. The search was performed as follows: ("Ulcerative colitis" OR “Crohn's disease" OR "inflammatory bowel diseases"

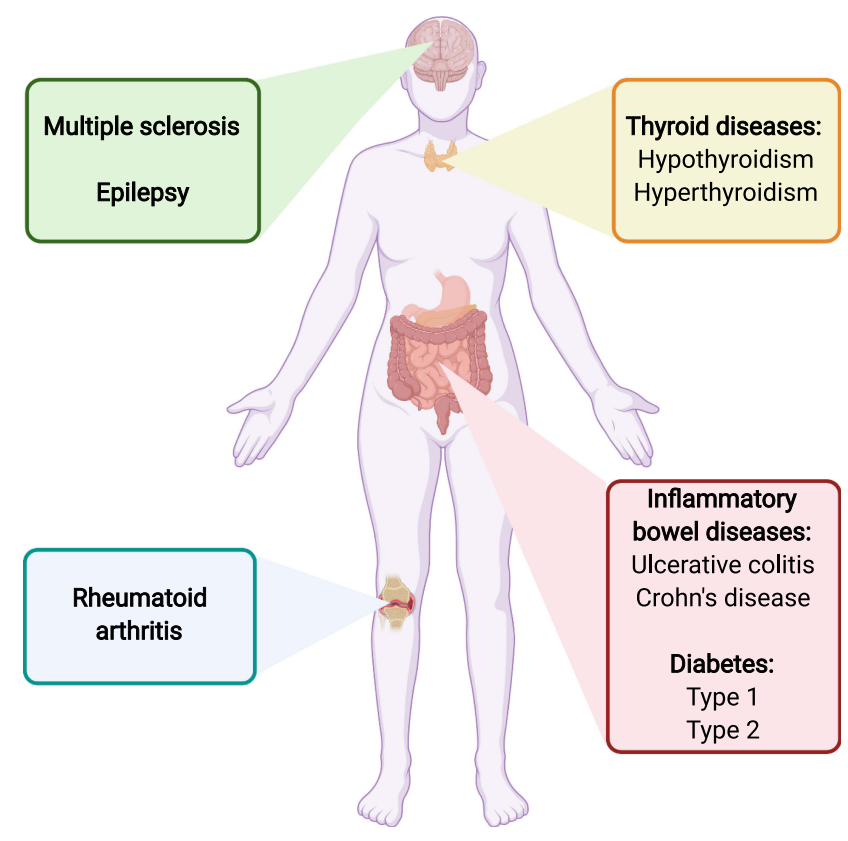

Figure I This review focuses on women with some of the most prevalent chronic diseases during the reproductive years. Created with BioRender.com.

OR "inflammatory bowel disease" OR "multiple sclerosis" OR "rheumatoid arthritis" OR diabetes type OR "epilepsy" OR "thyroid disease" OR "hypothyroidism" OR "hyperthyroidism" OR (corticosteroid AND (disease OR chronic))) AND ("live birth rate" OR "live birth" OR "clinical pregnancy" OR "biochemical pregnancy") AND ("assisted reproductive technology" OR "in vitro fertilization" OR "IVF" OR "assisted reproductive technologies"). Even if this was not a systematic review, to increase the reproducibility and accuracy of the study, the literature screening was conducted in accordance with the Preferred Reporting Items for Systematic reviews and Meta-Analyses [PRISMA] using the web-based program Covidence at the University Library of Southern Denmark.

To support the findings based on the PubMed.gov search strategy, we made additional searches in the Cochrane register and the Embase database without finding further papers.

\section{Outcomes}

The primary outcome of interest was live birth. We reviewed papers where live birth was calculated per embryo transfer, within a certain period from first ART treatment, or as cumulative live birth proportions. Secondary outcomes were biochemical pregnancy and clinical pregnancy in women with ulcerative colitis, 
Crohn's disease, rheumatoid arthritis, multiple sclerosis, epilepsy, thyroid disease, and diabetes mellitus.

\section{Exclusion Criteria}

We excluded papers where the outcomes of interest in women with the underlying chronic disease were not compared to outcomes in women in the general population receiving ART. Moreover, we excluded review papers and papers where the outcome, the disease of interest, or the study population were not relevant for our research question. Papers were eligible only if published in English.

\section{Study Selection}

The unified search provided us with a total of 56 results, and the authors were aware of an additional two papers (expert knowledge). ${ }^{7,8}$ One of these additional two papers was categorized as a comment. Title and abstracts of 58 papers were reviewed, and 37 papers were excluded. A total of 21 eligible papers were further investigated with a full-text screening. Seven papers were excluded as they did not include an external reference group, and one paper was excluded because the analyses were based on overall chapters from the International Classification of Disease (and not the specific diseases of interest). ${ }^{9}$ The overview is given in Figure 2 (PRISMA flow chart). A total of 13 papers were thus eligible for the review criteria. $^{7,8,10-20}$

\section{Results}

\section{The Efficacy of ART in Women with Inflammatory Bowel Diseases}

The proportion of women with chronic inflammatory bowel diseases (ulcerative colitis and Crohn's disease) with infertility problems is likely to be at least the same as in the general population or even higher due to adhesions of the fallopian tubes and ovaries associated with prior abdominal surgery. ${ }^{21,22}$ Former studies have found a considerable reduction in postoperative fertility in women with ulcerative colitis requiring ileoanal pouch anastomosis $^{23-25}$ and after CD surgery. ${ }^{26-28}$ Excluding voluntary childlessness, additional causes of infertility may include increased disease activity and low ovarian reserve. ${ }^{27,29,30}$ There is however very little research on the efficacy of ART in patients with ulcerative colitis and Crohn's disease.

\section{The Chance of a Live Born Child, Biochemical Pregnancy, and Clinical Pregnancy in Women with Ulcerative Colitis and Crohn's Disease}

The cumulative live birth rates in women with ulcerative colitis and Crohn's disease were reported for the first time in 2015 . $^{7,13}$ Oza et al reported the proportion of live born children in 71 patients with ulcerative colitis, 49 patients with Crohn's disease, and 470 women without IBD. ${ }^{7}$ The cohorts were matched according to maternal age, center of performed treatment, parity and diagnosis of infertility. The cumulative live birth rates after up to 6 cycles in women with ulcerative colitis, Crohn's disease and women without chronic inflammatory bowel diseases were $69 \%, 57 \%$, and $53 \%$, respectively (Table 1 ). ${ }^{7}$ The proportions of patients achieving biochemical/clinical pregnancies after the first ART procedure were also assessed, and in women with ulcerative colitis, Crohn's disease and women without chronic inflammatory bowel disease, these proportions were $49.3 \%, 42.9 \%$, and 40.9 , respectively (Table 2). The relative risk estimates were not calculated in the paper. ${ }^{7}$

The study by Pabby et al was based on the same cohorts of women with ulcerative colitis and women without chronic inflammatory bowel disease. ${ }^{13}$ They examined ART outcomes in the 22 women with ulcerative colitis who had undergone ileal pouch anal anastomosis and compared them to women with ulcerative colitis without surgery $(\mathrm{N}=49)$, and to women without chronic inflammatory bowel disease $(\mathrm{N}=470){ }^{13}$ The primary outcome was the cumulative live birth rate defined as the proportion of women who ultimately achieved one live birth at the end of the treatment course, which was up to 6 ART cycles. A total of $64 \%$ of women with ulcerative colitis, who had undergone ileal pouch anal anastomosis, $71 \%$ of women with ulcerative colitis without surgery, and $53 \%$ of women without the disease had a live birth (Table 1). The authors also assessed the chance of a biochemical/clinical pregnancy after the first ART cycle and the corresponding figures in these three cohorts were $40.9 \%, 53.1 \%$ and $40.9 \%$, respectively (Table 2). The paper was mainly descriptive, did not report relative risk estimates and did not control the analyses for confounding.

In 2016, based on nationwide Danish data, the efficacy of ART was examined in 1360 ART treatments in 432 women with ulcerative colitis, 554 ART treatments in 182 women with Crohn's disease, and in an unexposed 

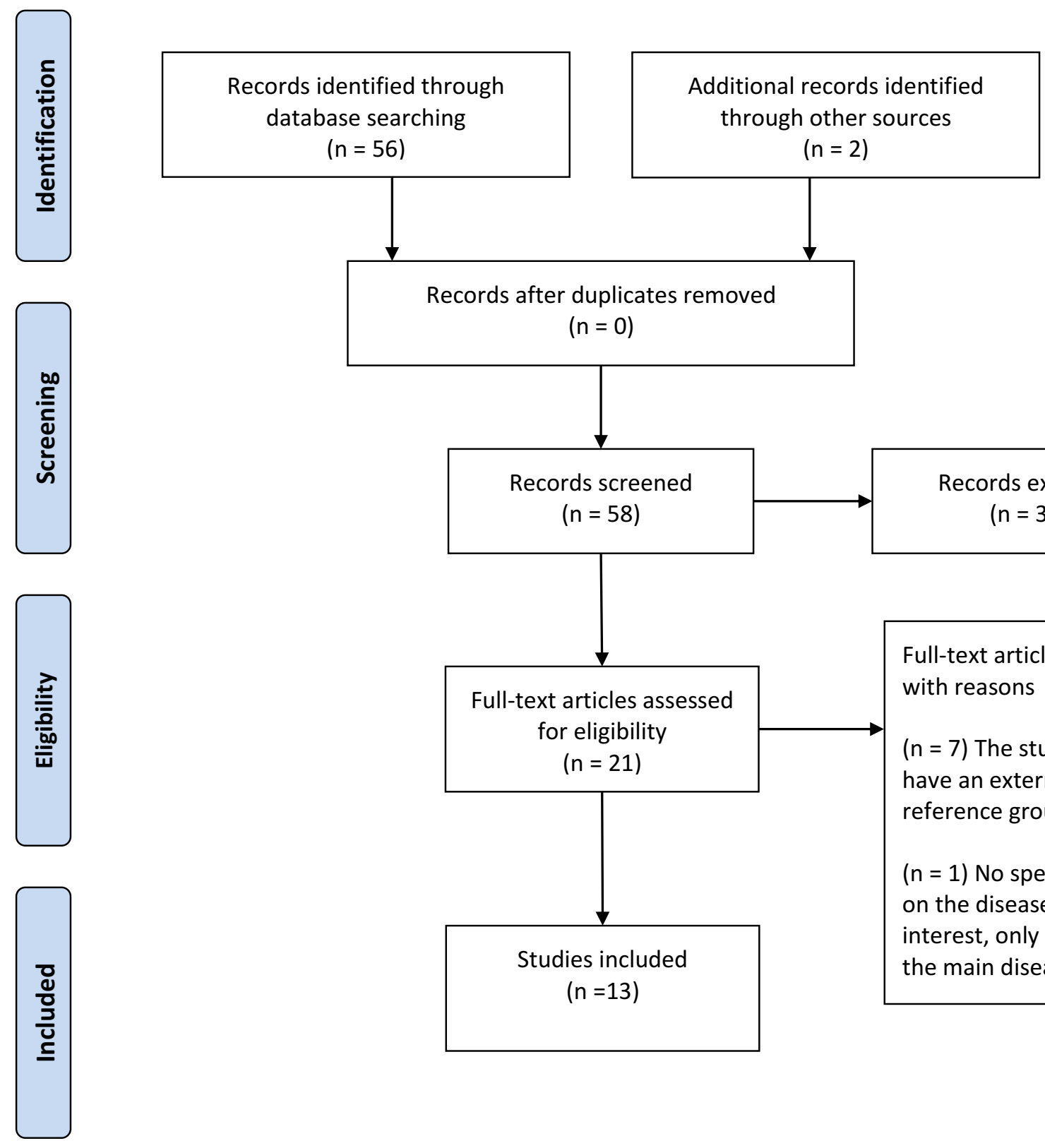

Records after duplicates removed

$(n=0)$
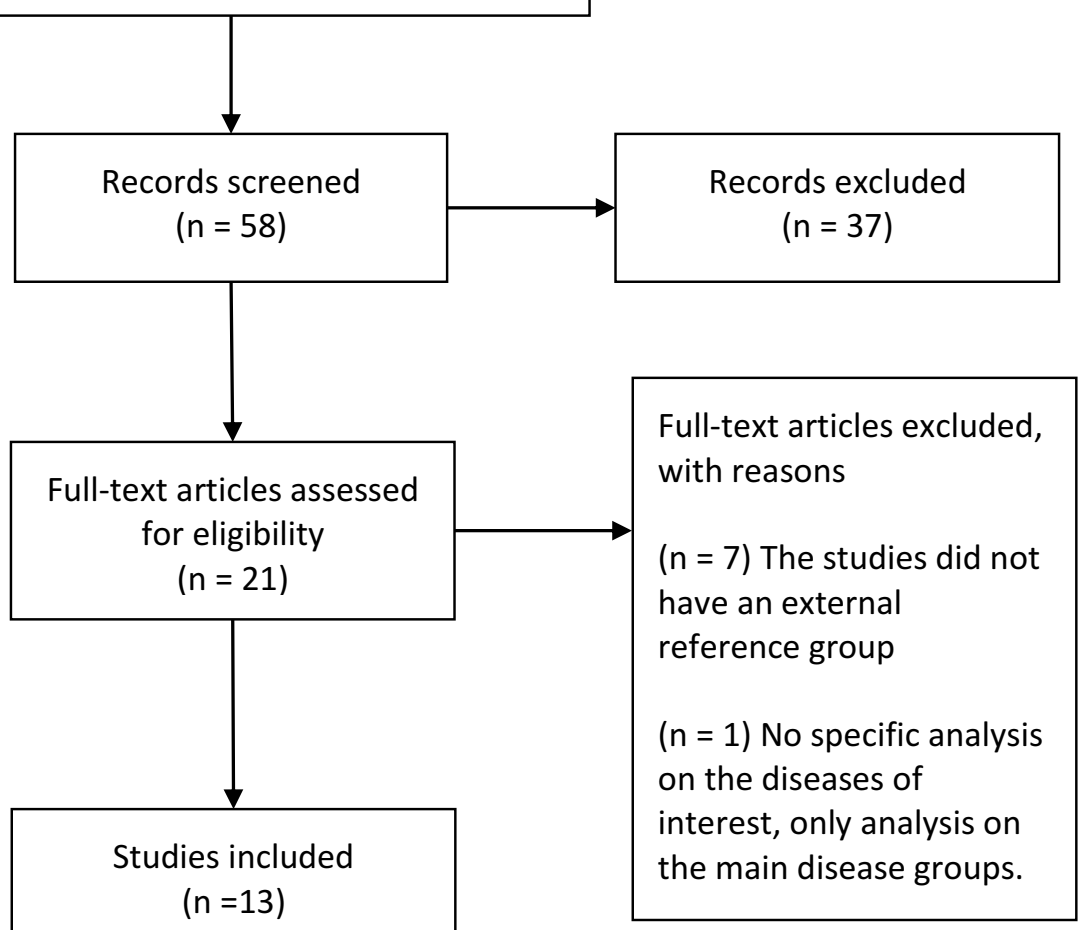

Figure 2 PRISMA flow chart, literature search.

Notes: Adapted from Liberati A, Altman D, Tetzlaff J, et al. The PRISMA statement for reporting systematic reviews and meta-analyses of studies that evaluate health care interventions: explanation and elaboration. Journal of Clinical Epidemiology. 2009;62(10). Creative Commons. ${ }^{98}$

cohort of 148,540 ART treatments in women without chronic inflammatory bowel disease. ${ }^{12}$ Among embryo transfers in patients with ulcerative colitis, the median duration of the disease at the time of embryo transfer was 8 years, and surgery had been performed prior to the transfer in $34.5 \%$ of the cases. Among embryo transfers in patients with Crohn's disease, the median duration of the disease at the time of embryo transfer was 9 years, and surgery had been performed prior to the transfer in $64.1 \%$ of the cases. The odds ratios (ORs) for ART treatments in women with ulcerative colitis and Crohn's disease leading to a live birth, compared to ART treatments in women without inflammatory bowel disease, are given in Table 1. The chance of a live birth was reduced per ART treatment in women with ulcerative colitis, and compared to the crude OR, the adjusted ORs were virtually unchanged across two different models (the OR was $0.78,95 \% \mathrm{CI}$ : 0.67 to 0.91 in the model with the best statistical precision). The chance of a live birth was reduced in women with Crohn's disease (adjusted OR 0.61, 95\% CI: 0.47 to 
Table I The Efficacy of Assisted Reproductive Technology Treatment and the Chance of Live Birth in Women with Underlying Chronic Diseases. The Included Papers are Sorted into Chronological Order with the Newest Publication from the Top (Within Each Disease Area)

\begin{tabular}{|c|c|c|c|c|c|c|}
\hline $\begin{array}{l}\text { Authorl } \\
\text { Year }\end{array}$ & Title & Design & Disease Area & $\begin{array}{l}\text { Number of Exposed } \\
\text { and Unexposed }\end{array}$ & Outcome & $\begin{array}{l}\text { Key Findings. In } \\
\text { Brackets: the } 95 \% \\
\text { Confidence Interval }\end{array}$ \\
\hline \multicolumn{7}{|c|}{ Inflammatory diseases } \\
\hline $\begin{array}{l}\text { Hernandez- } \\
\text { Nieto et al } \\
2020^{10}\end{array}$ & $\begin{array}{l}\text { Infertile patients with } \\
\text { inflammatory bowel } \\
\text { disease have comparable } \\
\text { in vitro fertilization clinical } \\
\text { outcomes to the general } \\
\text { infertile population }\end{array}$ & $\begin{array}{l}\text { Cohort } \\
\text { study }\end{array}$ & IBD & $\begin{array}{l}38 \text { IBD patients ( } 19 \text { with } \\
\text { UC and } 19 \text { with } C D) \text {, } \\
\text { and II } 4 \text { controls. } \\
\text { Fresh transfers were } \\
\text { excluded, and all } \\
\text { embryos had pre- } \\
\text { implantation genetic } \\
\text { diagnosis for abnormal } \\
\text { numbers of } \\
\text { chromosomes. }\end{array}$ & $\begin{array}{l}\text { Live birth per } \\
\text { embryo } \\
\text { transfer }\end{array}$ & $\begin{array}{l}\text { OR } 0.80(0.03-20.54)^{\mathrm{a}} \\
\text { Main analyses including } \\
\text { both UC and CD. } \\
\text { Matched study, but it is } \\
\text { unclear which clinical } \\
\text { variables the analysis is } \\
\text { adjusted for. }\end{array}$ \\
\hline \multirow[t]{2}{*}{$\begin{array}{l}\text { Friedman } \\
\text { et al } 2017^{11}\end{array}$} & $\begin{array}{l}\text { The Efficacy of Assisted } \\
\text { Reproduction in Women } \\
\text { with Inflammatory Bowel } \\
\text { Disease and the Impact of } \\
\text { Surgery-A Nationwide } \\
\text { Cohort Study }\end{array}$ & $\begin{array}{l}\text { Cohort } \\
\text { study }\end{array}$ & UC & $\begin{array}{l}38 \text { I women with UC } \\
50,32 \text { I without IBD } \\
\text { Impact of surgery: I2I } \\
\text { women with UC had } \\
\text { surgery before ART } \\
\text { compared to } 260 \text { women } \\
\text { with UC who did not } \\
\text { have surgery before ART. } \\
\text { Include IVF, with or } \\
\text { without ICSI, and } \\
\text { transfer of FER embryos. }\end{array}$ & $\begin{array}{l}\text { Live birth } \\
\text { within } 18 \\
\text { months after } \\
\text { the first } \\
\text { embryo } \\
\text { transfer }\end{array}$ & $\begin{array}{l}\text { OR } 0.92(0.76-I . I 3) \\
\text { aOR } 0.87(0.7 \mathrm{I}-\mathrm{I} .07)^{\mathrm{b}} \\
\text { Impact of surgery: OR } \\
0.84(0.55-1.30) \\
\text { aOR } 0.8 \mathrm{I}(0.47-1.39)^{\mathrm{c}} \\
\text { Analyses adjusted for } \\
\text { confounders. }\end{array}$ \\
\hline & & & $C D$ & $\begin{array}{l}\text { I } 58 \text { women with CD } \\
50,32 \text { I without IBD } \\
\text { Impact of surgery: } 86 \\
\text { women with CD had } \\
\text { surgery before ART } \\
\text { compared to } 72 \text { women } \\
\text { with CD who did not } \\
\text { have surgery before ART. } \\
\text { Include IVF, with or } \\
\text { without ICSI, and } \\
\text { transfer of FER embryos. }\end{array}$ & $\begin{array}{l}\text { Live birth } \\
\text { within } 18 \\
\text { months after } \\
\text { the first } \\
\text { embryo } \\
\text { transfer }\end{array}$ & $\begin{array}{l}\text { OR } 0.64(0.47-0.83) \\
\text { aOR } 0.59(0.42-0.83)^{b} \\
\text { Impact of surgery: OR } \\
0.37(0.19-0.7 \mathrm{I}) \\
\text { aOR } 0.29(0.13-0.65)^{\mathrm{c}} \\
\text { Analyses adjusted for } \\
\text { confounders. }\end{array}$ \\
\hline $\begin{array}{l}\text { Friedman } \\
\text { et al } 2017^{8}\end{array}$ & $\begin{array}{l}\text { The reduced chance of } \\
\text { a live birth in women with } \\
\text { IBD receiving assisted } \\
\text { reproduction is due to } \\
\text { a failure to achieve a clinical } \\
\text { pregnancy }\end{array}$ & $\begin{array}{l}\text { Cohort } \\
\text { study }\end{array}$ & UC & $\begin{array}{l}\text { In those with positive } \\
\text { biochemical pregnancy/ } \\
\text { clinical pregnancy: } 30 \text { I } \\
\text { embryo transfers in } \\
\text { women with UC, and } \\
40,552 \text { in women } \\
\text { without IBD. } \\
\text { Include IVF, with or } \\
\text { without ICSI, and } \\
\text { transfer of FER embryos. }\end{array}$ & $\begin{array}{l}\text { Live birth } \\
\text { among those } \\
\text { with positive } \\
\text { biochemical } \\
\text { pregnancy/ } \\
\text { clinical } \\
\text { pregnancy }\end{array}$ & $\begin{array}{l}\text { aOR I.I6 (0.75-I.79) } \\
\text { Analyses adjusted for } \\
\text { confounders. }\end{array}$ \\
\hline
\end{tabular}

(Continued) 
Table I (Continued).

\begin{tabular}{|c|c|c|c|c|c|c|}
\hline $\begin{array}{l}\text { Authorl } \\
\text { Year }\end{array}$ & Title & Design & Disease Area & $\begin{array}{l}\text { Number of Exposed } \\
\text { and Unexposed }\end{array}$ & Outcome & $\begin{array}{l}\text { Key Findings. In } \\
\text { Brackets: the } 95 \% \\
\text { Confidence Interval }\end{array}$ \\
\hline & & & $C D$ & $\begin{array}{l}\text { In those with positive } \\
\text { biochemical pregnancy/ } \\
\text { clinical pregnancy: I07 } \\
\text { embryo transfers in } \\
\text { women with CD, and } \\
40,552 \text { in women } \\
\text { without IBD. } \\
\text { Includes IVF, with or } \\
\text { without ICSI, and } \\
\text { transfer of FER embryos. }\end{array}$ & $\begin{array}{l}\text { Live birth } \\
\text { among those } \\
\text { with positive } \\
\text { biochemical } \\
\text { pregnancy/ } \\
\text { clinical } \\
\text { pregnancy }\end{array}$ & $\begin{array}{l}\text { aOR } 0.89(0.44-1.83)^{\mathrm{d}} \\
\text { Analyses adjusted for } \\
\text { confounders. }\end{array}$ \\
\hline \multirow[t]{2}{*}{$\begin{array}{l}\text { Nørgård } \\
\text { et al } 2016^{12}\end{array}$} & $\begin{array}{l}\text { Live birth and adverse birth } \\
\text { outcomes in women with } \\
\text { ulcerative colitis and } \\
\text { Crohn's disease receiving } \\
\text { assisted reproduction: } \\
\text { a } 20 \text {-year nationwide } \\
\text { cohort study }\end{array}$ & $\begin{array}{l}\text { Cohort } \\
\text { study }\end{array}$ & UC & $\begin{array}{l}432 \text { women with UC and } \\
52,489 \text { women without } \\
\text { IBD. } \\
\text { Include IVF, with or } \\
\text { without ICSI, and } \\
\text { transfer of FER embryos. }\end{array}$ & $\begin{array}{l}\text { Live birth per } \\
\text { embryo } \\
\text { transfer }\end{array}$ & $\begin{array}{l}\text { OR } 0.79(0.67-0.92) \\
\text { aOR } 0.78(0.67-0.91)^{\mathrm{e}} \\
\text { aOR } 0.73(0.58-0.92)^{\mathrm{f}} \\
\text { Analyses adjusted for } \\
\text { confounders. }\end{array}$ \\
\hline & & & $C D$ & $\begin{array}{l}\text { I } 82 \text { women with CD and } \\
52,489 \text { women without } \\
\text { IBD. } \\
\text { Include IVF, with or } \\
\text { without ICSI, and } \\
\text { transfer of FER embryos. }\end{array}$ & $\begin{array}{l}\text { Live birth per } \\
\text { embryo } \\
\text { transfer }\end{array}$ & $\begin{array}{l}\text { OR } 0.62(0.48-0.80) \\
\text { aOR } 0.61(0.47-0.79)^{\mathrm{e}} \\
\text { aOR } 0.77(0.52-1.14)^{\mathrm{f}} \\
\text { Analyses adjusted for } \\
\text { confounders. }\end{array}$ \\
\hline $\begin{array}{l}\text { Pabby et al } \\
2015^{13}\end{array}$ & $\begin{array}{l}\text { In Vitro Fertilization Is } \\
\text { Successful in Women With } \\
\text { Ulcerative Colitis and Ileal } \\
\text { Pouch Anal Anastomosis }\end{array}$ & $\begin{array}{l}\text { Cohort } \\
\text { study }\end{array}$ & UC & $\begin{array}{l}22 \text { women with UC, who } \\
\text { had undergone ileal } \\
\text { pouch anal anastomosis. } \\
49 \text { women with UC } \\
\text { without surgery. } \\
470 \text { women without IBD. }\end{array}$ & $\begin{array}{l}\text { Live birth } \\
\text { after } \\
\text { cumulative } \\
\text { cycles }\end{array}$ & $\begin{array}{l}\text { After first cycle: } \\
\text { Women with UC, who } \\
\text { had undergone surgery } \\
27 \% \text { (I3-52\%). } \\
\text { Women with UC } \\
\text { without surgery } 37 \% \\
\text { (25-52\%). Women } \\
\text { without IBD: } 30 \% \\
\text { (26-35\%). } \\
\text { After six cycles: Women } \\
\text { with UC, who had } \\
\text { undergone surgery } 64 \% \\
\text { (44-83\%). } \\
\text { Women with UC } \\
\text { without surgery } 7 \text { I \% } \\
\text { (59-83\%). } \\
\text { Women without IBD: } \\
53 \% \text { (48-57\%). } \\
\text { No relative risk } \\
\text { estimates were } \\
\text { calculated. } \\
\text { No adjustment for } \\
\text { confounding }\end{array}$ \\
\hline
\end{tabular}

(Continued) 
Table I (Continued).

\begin{tabular}{|c|c|c|c|c|c|c|}
\hline $\begin{array}{l}\text { Authorl } \\
\text { Year }\end{array}$ & Title & Design & Disease Area & $\begin{array}{l}\text { Number of Exposed } \\
\text { and Unexposed }\end{array}$ & Outcome & $\begin{array}{l}\text { Key Findings. In } \\
\text { Brackets: the } 95 \% \\
\text { Confidence Interval }\end{array}$ \\
\hline $\begin{array}{l}\text { Oza et al } \\
2015^{7}\end{array}$ & $\begin{array}{l}\text { In Vitro Fertilization in } \\
\text { Women With } \\
\text { Inflammatory Bowel } \\
\text { Disease Is as Successful as } \\
\text { in Women From the } \\
\text { General Infertility } \\
\text { Population }\end{array}$ & $\begin{array}{l}\text { Cohort } \\
\text { study }\end{array}$ & IBD & $\begin{array}{l}49 \text { patients with CD. } \\
7 \text { I patients with UC. } \\
\text { I patient with IBD- } \\
\text { unclassified. } \\
470 \text { women without IBD. }\end{array}$ & $\begin{array}{l}\text { Live birth } \\
\text { after } \\
\text { cumulative } \\
\text { cycles }\end{array}$ & $\begin{array}{l}\text { After first cycle: } \\
\text { Women with UC } 33.8 \% \text {. } \\
\text { Women with CD } 30.6 \% \text {. } \\
\text { Women without IBD } \\
30.2 \% \text {. } \\
\text { After six cycles: UC } \\
69 \% \text { (58-79\%) } \\
\text { CD 57\% (44-7I\%) } \\
\text { Non-IBD: } 53 \% \\
\text { (48-57\%) } \\
\text { Cohorts were matched } \\
\text { on some maternal } \\
\text { factors (eg age, parity, } \\
\text { cause of infertility). } \\
\text { No relative risk } \\
\text { estimates were } \\
\text { calculated. }\end{array}$ \\
\hline \multirow[t]{2}{*}{$\begin{array}{l}\text { Nørgård } \\
\text { et al } 2019^{14}\end{array}$} & $\begin{array}{l}\text { Decreased chance of a live } \\
\text { born child in women with } \\
\text { rheumatoid arthritis after } \\
\text { assisted reproduction } \\
\text { treatment: a nationwide } \\
\text { cohort study }\end{array}$ & $\begin{array}{l}\text { Cohort } \\
\text { study }\end{array}$ & $\begin{array}{l}\text { Rheumatoid } \\
\text { arthritis }\end{array}$ & $\begin{array}{l}\text { II } 49 \text { embryo transfers in } \\
\text { women with rheumatoid } \\
\text { arthritis. } \\
\text { I98,94I embryo } \\
\text { transfers in women } \\
\text { without rheumatoid } \\
\text { arthritis. } \\
\text { Include IVF, with or } \\
\text { without ICSI, and } \\
\text { transfer of FER embryos. }\end{array}$ & $\begin{array}{l}\text { Live birth per } \\
\text { embryo } \\
\text { transfer }\end{array}$ & $\begin{array}{l}\text { OR } 0.70(0.59-0.84) \\
\text { aOR } 0.78(0.65-0.92)^{\mathrm{e}} \\
\text { Analyses adjusted for } \\
\text { confounders. }\end{array}$ \\
\hline & & & & $\begin{array}{l}259 \text { embryo transfers in } \\
\text { women with rheumatoid } \\
\text { arthritis that were } \\
\text { preceded by } \\
\text { corticosteroid, and } 886 \\
\text { that were not. } \\
\text { Include IVF, with or } \\
\text { without ICSI, and } \\
\text { transfer of FER embryos. }\end{array}$ & $\begin{array}{l}\text { Live birth per } \\
\text { embryo } \\
\text { transfer }\end{array}$ & $\begin{array}{l}\text { OR I.20 }(0.8 \mathrm{I}-\mathrm{I} .77) \\
\text { aORI.32 }(0.85-2.05)^{\mathrm{g}} \\
\text { Analyses adjusted for } \\
\text { confounders. }\end{array}$ \\
\hline \multicolumn{7}{|c|}{ Neurological diseases } \\
\hline $\begin{array}{l}\text { Jølving et al } \\
2020^{15}\end{array}$ & $\begin{array}{l}\text { Live birth in women with } \\
\text { multiple sclerosis receiving } \\
\text { assisted reproduction }\end{array}$ & $\begin{array}{l}\text { Cohort } \\
\text { study }\end{array}$ & $\begin{array}{l}\text { Multiple } \\
\text { sclerosis }\end{array}$ & $\begin{array}{l}2267 \text { embryo transfers in } \\
\text { women with multiple } \\
\text { sclerosis. } \\
200,684 \text { embryo } \\
\text { transfers in women } \\
\text { without multiple } \\
\text { sclerosis. } \\
\text { Include IVF, with or } \\
\text { without ICSI, and } \\
\text { transfer of FER embryos. }\end{array}$ & $\begin{array}{l}\text { Live birth per } \\
\text { embryo } \\
\text { transfer }\end{array}$ & $\begin{array}{l}\text { OR } 0.85(0.76-0.96) \\
\text { aOR } 0.91(0.8 I-1.02)^{\mathrm{e}} \\
\text { Analyses adjusted for } \\
\text { confounders. }\end{array}$ \\
\hline
\end{tabular}

(Continued) 
Table I (Continued).

\begin{tabular}{|c|c|c|c|c|c|c|}
\hline \multirow[t]{2}{*}{$\begin{array}{l}\text { Authorl } \\
\text { Year }\end{array}$} & Title & Design & Disease Area & $\begin{array}{l}\text { Number of Exposed } \\
\text { and Unexposed }\end{array}$ & Outcome & $\begin{array}{l}\text { Key Findings. In } \\
\text { Brackets: the } 95 \% \\
\text { Confidence Interval }\end{array}$ \\
\hline & & & & $\begin{array}{l}100 \text { embryo transfers } \\
\text { were preceded by } \\
\text { corticosteroid and } 2167 \\
\text { were not. }\end{array}$ & $\begin{array}{l}\text { Live birth per } \\
\text { embryo } \\
\text { transfer }\end{array}$ & $\begin{array}{l}\text { OR } 0.87(0.49-1.52) \\
\text { aOR } 0.90(0.49-1.68)^{\mathrm{e}} \\
\text { Analyses adjusted for } \\
\text { confounders. }\end{array}$ \\
\hline $\begin{array}{l}\text { Larsen et al } \\
2020^{16}\end{array}$ & $\begin{array}{l}\text { The efficacy of assisted } \\
\text { reproductive treatment in } \\
\text { women with epilepsy }\end{array}$ & $\begin{array}{l}\text { Cohort } \\
\text { study }\end{array}$ & Epilepsy & $\begin{array}{l}730 \text { ART treatments in } \\
264 \text { women with } \\
\text { epilepsy. } \\
\text { 128,387 ART treatments } \\
\text { in } 42,938 \text { women } \\
\text { without epilepsy. }\end{array}$ & $\begin{array}{l}\text { Live birth per } \\
\text { embryo } \\
\text { transfer }\end{array}$ & $\begin{array}{l}\text { OR I.03 }(0.86-1.25) \\
\text { aOR I.06 }(0.88-1.28)^{\mathrm{h}} \\
\text { Analyses adjusted for } \\
\text { confounders. }\end{array}$ \\
\hline \multicolumn{7}{|c|}{ Endocrinological diseases } \\
\hline \multirow[t]{2}{*}{$\begin{array}{l}\text { Jølving et al } \\
2019^{17}\end{array}$} & $\begin{array}{l}\text { The chance of a live birth } \\
\text { after assisted reproduction } \\
\text { in women with thyroid } \\
\text { disorders }\end{array}$ & $\begin{array}{l}\text { Cohort } \\
\text { study }\end{array}$ & Hyperthyroidism & $\begin{array}{l}2010 \text { embryo transfers in } \\
\text { women with } \\
\text { hyperthyroidism and } \\
193,972 \text { embryo } \\
\text { transfers in women } \\
\text { without thyroid disease. }\end{array}$ & $\begin{array}{l}\text { Live birth per } \\
\text { embryo } \\
\text { transfer }\end{array}$ & $\begin{array}{l}\text { OR } 0.74(0.65-0.84) \\
\text { aOR } 0.86(0.76-0.98)^{\mathrm{e}} \\
\text { Analyses adjusted for } \\
\text { confounders. }\end{array}$ \\
\hline & & & Hypothyroidism & $\begin{array}{l}3692 \text { embryo transfers in } \\
\text { women with } \\
\text { hypothyroidism and } \\
193,972 \text { embryo } \\
\text { transfers in women } \\
\text { without thyroid disease. }\end{array}$ & $\begin{array}{l}\text { Live birth per } \\
\text { embryo } \\
\text { transfer }\end{array}$ & $\begin{array}{l}\text { OR } 0.99(0.90-1.08) \\
\text { aOR I.03 }(0.94-1.12)^{\mathrm{e}} \\
\text { Analyses adjusted for } \\
\text { confounders. }\end{array}$ \\
\hline $\begin{array}{l}\text { Unuane } \\
\text { et al } 2016^{18}\end{array}$ & $\begin{array}{l}\text { Impact of thyroid } \\
\text { autoimmunity on } \\
\text { cumulative delivery rates } \\
\text { after in in vitro fertilization/ } \\
\text { intracytoplasmic sperm } \\
\text { injection patients }\end{array}$ & $\begin{array}{l}\text { Cohort } \\
\text { study }\end{array}$ & TAl status & $\begin{array}{l}333 \text { patients with } \\
\text { positive TAl status and } \\
2019 \text { patients without } \\
\text { positive TAl. Those with } \\
\text { clinical thyroid } \\
\text { dysfunction were } \\
\text { excluded. }\end{array}$ & $\begin{array}{l}\text { Cumulative } \\
\text { live birth } \\
\text { after } 25 \\
\text { weeks of } \\
\text { gestation }\end{array}$ & $\begin{array}{l}\text { The crude cumulative } \\
\text { delivery rate (\%) in TAI } \\
\text { positive patients after } 6 \\
\text { cycles: } 47 \% \text {. } \\
\text { The crude cumulative } \\
\text { delivery rate (\%) in TAI } \\
\text { negative patients after } 6 \\
\text { cycles: } 47 \% \text {. } \\
\text { A regression model } \\
\text { including thyroid related } \\
\text { variables, and clinical } \\
\text { variables, concluded } \\
\text { that age was the most } \\
\text { important factor for live } \\
\text { birth. } \\
\text { No relative risk } \\
\text { estimates were } \\
\text { presented in the paper. }\end{array}$ \\
\hline
\end{tabular}

(Continued) 
Table I (Continued).

\begin{tabular}{|c|c|c|c|c|c|c|}
\hline $\begin{array}{l}\text { Authorl } \\
\text { Year }\end{array}$ & Title & Design & Disease Area & $\begin{array}{l}\text { Number of Exposed } \\
\text { and Unexposed }\end{array}$ & Outcome & $\begin{array}{l}\text { Key Findings. In } \\
\text { Brackets: the } 95 \% \\
\text { Confidence Interval }\end{array}$ \\
\hline $\begin{array}{l}\text { Chai et al } \\
2014^{19}\end{array}$ & $\begin{array}{l}\text { Live birth rates following } \\
\text { in vitro fertilization in } \\
\text { women with TAI and/or } \\
\text { subclinical hypothyroidism }\end{array}$ & $\begin{array}{l}\text { Cohort } \\
\text { study }\end{array}$ & TAl status & $\begin{array}{l}\text { I } 22 \text { TAl positive women } \\
\text { ( } 89 \text { were euthyroid, } 33 \\
\text { were subclinical } \\
\text { hypothyroid) and } 505 \\
\text { TAI negative ( } 419 \text { were } \\
\text { euthyroid and } 85 \text { were } \\
\text { subclinical hypothyroid). }\end{array}$ & $\begin{array}{l}\text { Live birth per } \\
\text { fresh first } \\
\text { cycle }\end{array}$ & $\begin{array}{l}\text { In subclinical } \\
\text { hypothyroidism TAI } \\
\text { positive: } 33.3 \% \text {. } \\
\text { In euthyroid TAI } \\
\text { positive: } 32.6 \% \text {. } \\
\text { In subclinical } \\
\text { hypothyroidism TAI } \\
\text { negative: } 36.0 \% \text {. } \\
\text { In euthyroid TAI } \\
\text { negative: } 36.0 \% \text {. } \\
\text { No relative risk } \\
\text { estimates were } \\
\text { calculated. } \\
\text { No adjustment for } \\
\text { confounding. }\end{array}$ \\
\hline \multirow[t]{2}{*}{$\begin{array}{l}\text { Larsen et al } \\
2020^{20}\end{array}$} & $\begin{array}{l}\text { Live-born children after } \\
\text { assisted reproduction in } \\
\text { women with type I } \\
\text { diabetes and type } 2 \\
\text { diabetes: a nationwide } \\
\text { cohort study }\end{array}$ & $\begin{array}{l}\text { Cohort } \\
\text { study }\end{array}$ & $\begin{array}{l}\text { Diabetes } \\
\text { Mellitus type I }\end{array}$ & $\begin{array}{l}538 \text { embryo transfers in } \\
\text { I87 women with type I } \\
\text { diabetes, and } 127,599 \\
\text { embryo transfers in } \\
42,688 \text { women without } \\
\text { diabetes. }\end{array}$ & $\begin{array}{l}\text { Live birth per } \\
\text { embryo } \\
\text { transfer }\end{array}$ & $\begin{array}{l}\text { OR I.I4 }(0.9 I-I .43) \\
\text { aOR I.I0 }(0.86-I .4 I)^{\mathrm{i}} \\
\text { Analyses adjusted for } \\
\text { confounders. }\end{array}$ \\
\hline & & & $\begin{array}{l}\text { Diabetes } \\
\text { Mellitus Type } 2\end{array}$ & $\begin{array}{l}518 \text { embryo transfers in } \\
179 \text { women with type } 2 \\
\text { diabetes, and } 127,599 \\
\text { embryo transfers in } \\
42,688 \text { women without } \\
\text { diabetes. }\end{array}$ & $\begin{array}{l}\text { Live birth per } \\
\text { embryo } \\
\text { transfer }\end{array}$ & $\begin{array}{l}\text { OR } 0.46(0.34-0.6 \mathrm{I}) \\
\text { aOR } 0.50(0.36-0.7 \mathrm{I})^{\mathrm{i}} \\
\text { Analyses adjusted for } \\
\text { confounders. }\end{array}$ \\
\hline
\end{tabular}

Notes: ${ }^{a}$ Matched according to oocyte age at retrieval, body mass index, anti-Müllerian hormone, and basal antral follicle count. ${ }^{\mathrm{b}}$ Adjusted for Charlson Index, women's age, calendar year of treatment, treatment type, female/male factor. 'Adjusted for duration of UC/CD, Charlson Index, women's age, calendar year of treatment, treatment type, female/male factor. 'Adjusted for: Charlson Index, women's age, calendar year of treatment, type of treatment (IVF, ICSI, FER), cause of infertility (female factor, male factor,

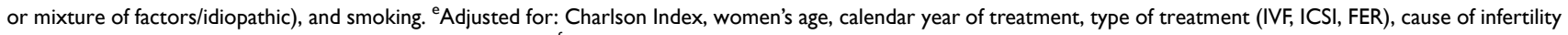
(female factor, male factor, or mixture of factors/idiopathic). 'Extended model using data from 2006, adjusted for: Charlson Index, women's age, calendar year of treatment, type of treatment (IVF, ICSI, FER), cause of infertility (female factor, male factor, or mixture of factors/idiopathic), body mass index, partner's age, smoking at the time of embryo transfer, and alcohol. ${ }^{8}$ Adjusted for Charlson Index, women's age, calendar year of treatment, type of treatment (IVF, ICSI, FER), cause of infertility (female factor, male factor, or mixture of factors/idiopathic), and disease duration of rheumatoid arthritis. 'Adjusted for women's age, calendar year of treatment, cause of infertility (female factor, male factor, or mixture of factors/idiopathic), body mass index, smoking and alcohol. 'Adjusted for women's age, calendar year of treatment, cause of infertility (female factor, male factor, or a mixture of factors/idiopathic), body mass index, smoking at the time of embryo transfer and alcohol.

Abbreviations: ART, assisted reproductive technology; CD, Crohn's disease; FER, frozen-thawed embryos; IBD, inflammatory bowel disease; IVF, in vitro fertilization; ICSI, intracytoplasmic sperm injection; OR, crude odds ratio; aOR, adjusted odds ratio; TAl, thyroid autoimmunity; UC, ulcerative colitis.

0.79), Table 1. The study also suggested that former surgery for Crohn's disease significantly reduced the chance of a live birth (adjusted OR 0.51, 95\% CI: 0.29 to 0.91 ), but for ulcerative colitis, the result suggested no negative impact of former surgery on the chance of a live birth. ${ }^{12}$ In 2017, based on the same Danish data as the study from Nørgård et $\mathrm{al}^{12}$ Friedman et al used a different analytic approach and analyzed the chance of a live birth per woman rather than per ART cycle. ${ }^{11}$ The study examined a live birth within a period of 18 months from the start of ART, and in women with ulcerative colitis, the adjusted OR for a live born child was 0.87 (95\% CI: 0.71 to 1.07) in the adjusted model with the best statistical precision, and for women with Crohn's disease the adjusted OR was 0.59 (95\% CI: 0.42 to 0.83 ) (Table 1). The impact of surgery was also studied in this alternative analytic approach, and the study confirmed that former surgery for Crohn's disease was significantly associated with 
Table 2 The Efficacy of Assisted Reproductive Technology Treatment and the Chance of Biochemical Pregnancy or Clinical Pregnancy in Women with Underlying Chronic Diseases. Not All of the Papers Included in This Review Examined These Outcomes

\begin{tabular}{|c|c|c|c|c|c|c|}
\hline $\begin{array}{l}\text { Authorl } \\
\text { Year }\end{array}$ & Title & Design & Disease Area & $\begin{array}{l}\text { Number of Exposed } \\
\text { and Unexposed }\end{array}$ & Outcome & $\begin{array}{l}\text { Key Findings. In } \\
\text { Brackets: the } \\
95 \% \text { Confidence } \\
\text { Interval }\end{array}$ \\
\hline \multicolumn{7}{|c|}{ Inflammatory diseases } \\
\hline \multirow[t]{2}{*}{$\begin{array}{l}\text { Hernandez- } \\
\text { Nieto et al } \\
2020^{10}\end{array}$} & $\begin{array}{l}\text { Infertile patients with } \\
\text { inflammatory bowel disease } \\
\text { have comparable in vitro } \\
\text { fertilization clinical outcomes to } \\
\text { the general infertile population }\end{array}$ & $\begin{array}{l}\text { Cohort } \\
\text { study }\end{array}$ & IBD & $\begin{array}{l}38 \text { embryo transfers in } 38 \\
\text { women with IBD matched } \\
\text { to II } 4 \text { controls without } \\
\text { IBD. } \\
\text { FER only + ICSI }\end{array}$ & $\begin{array}{l}\text { Implantation } \\
\text { per embryo } \\
\text { transfer }\end{array}$ & $\begin{array}{l}\text { aOR } 0.68 \\
(0.3-I .5)^{\mathrm{a}} \\
\text { Matched study, } \\
\text { but it is unclear } \\
\text { which clinical } \\
\text { variables the } \\
\text { analysis is adjusted } \\
\text { for. }\end{array}$ \\
\hline & & & & $\begin{array}{l}38 \text { embryo transfers in } 38 \\
\text { women with CD matched } \\
\text { to II } 4 \text { controls without } \\
\text { IBD. } \\
\text { FER only + ICSI }\end{array}$ & $\begin{array}{l}\text { Clinical } \\
\text { pregnancy } \\
\text { per embryo } \\
\text { transfer }\end{array}$ & $\begin{array}{l}\text { aOR } 0.68 \\
(0.2-1.8)^{\mathrm{a}} \\
\text { It is unclear which } \\
\text { clinical variables } \\
\text { the analysis is } \\
\text { adjusted for. }\end{array}$ \\
\hline \multirow[t]{2}{*}{$\begin{array}{l}\text { Friedman } \\
\text { et al } 2017^{8}\end{array}$} & $\begin{array}{l}\text { The reduced chance of a live } \\
\text { birth in women with IBD } \\
\text { receiving assisted reproduction } \\
\text { is due to a failure to achieve } \\
\text { a clinical pregnancy }\end{array}$ & $\begin{array}{l}\text { Cohort } \\
\text { study }\end{array}$ & UC & $\begin{array}{l}\text { I } 348 \text { embryo transfers in } \\
\text { women with UC, and } \\
\text { I47,348 in women } \\
\text { without IBD. } \\
\text { Include IVF, with or } \\
\text { without ICSI, and transfer } \\
\text { of FER embryos. }\end{array}$ & $\begin{array}{l}\text { Biochemical } \\
\text { pregnancy/ } \\
\text { clinical } \\
\text { pregnancy } \\
\text { per embryo } \\
\text { transfer }\end{array}$ & $\begin{array}{l}\text { aOR } 0.67 \\
(0.53-0.84)^{b} \\
\text { Analyses adjusted } \\
\text { for confounders. }\end{array}$ \\
\hline & & & $C D$ & $\begin{array}{l}552 \text { embryo transfers in } \\
\text { women with CD, and } \\
\text { I47,348 in women } \\
\text { without IBD. } \\
\text { Include IVF, with or } \\
\text { without ICSI, and transfer } \\
\text { of FER embryos. }\end{array}$ & $\begin{array}{l}\text { Biochemical } \\
\text { pregnancy/ } \\
\text { clinical } \\
\text { pregnancy } \\
\text { per embryo } \\
\text { transfer }\end{array}$ & $\begin{array}{l}\text { aOR } 0.75 \\
(0.5 \mathrm{I}-\mathrm{I} . \mathrm{I0})^{\mathrm{b}} \\
\text { Analyses adjusted } \\
\text { for confounders. }\end{array}$ \\
\hline $\begin{array}{l}\text { Pabby et al } \\
2015^{13}\end{array}$ & $\begin{array}{l}\text { In Vitro Fertilization Is } \\
\text { Successful in Women With } \\
\text { Ulcerative Colitis and lleal } \\
\text { Pouch Anal Anastomosis }\end{array}$ & $\begin{array}{l}\text { Cohort } \\
\text { study }\end{array}$ & UC & $\begin{array}{l}22 \text { patients with UC and } \\
\text { ileal pouch anal } \\
\text { anastomosis. } \\
49 \text { patients with UC and } \\
\text { without ileal pouch anal } \\
\text { anastomosis. } \\
470 \text { patients without IBD. } \\
\text { Include IVF } \pm \text { ICSI + } \\
\text { transfer of FER and fresh } \\
\text { embryos. }\end{array}$ & $\begin{array}{l}\text { Biochemical/ } \\
\text { clinical } \\
\text { pregnancy } \\
\text { after first } \\
\text { ART cycle }\end{array}$ & $\begin{array}{l}\text { Women with UC, } \\
\text { who had } \\
\text { undergone } \\
\text { surgery: } 40.9 \% \text {. } \\
\text { Women with UC } \\
\text { without surgery: } \\
53.1 \% \text {. } \\
\text { Women without } \\
\text { IBD: } 40.9 \% \text {. } \\
\text { No relative risk } \\
\text { estimates were } \\
\text { calculated. } \\
\text { No adjustment for } \\
\text { confounding. }\end{array}$ \\
\hline
\end{tabular}

(Continued) 
Table 2 (Continued).

\begin{tabular}{|c|c|c|c|c|c|c|}
\hline $\begin{array}{l}\text { Authorl } \\
\text { Year }\end{array}$ & Title & Design & Disease Area & $\begin{array}{l}\text { Number of Exposed } \\
\text { and Unexposed }\end{array}$ & Outcome & $\begin{array}{l}\text { Key Findings. In } \\
\text { Brackets: the } \\
95 \% \text { Confidence } \\
\text { Interval }\end{array}$ \\
\hline $\begin{array}{l}\text { Oza et al } \\
2015^{7}\end{array}$ & $\begin{array}{l}\text { In Vitro Fertilization in Women } \\
\text { With Inflammatory Bowel } \\
\text { Disease Is as Successful as in } \\
\text { Women From the General } \\
\text { Infertility Population }\end{array}$ & $\begin{array}{l}\text { Cohort } \\
\text { study }\end{array}$ & IBD & $\begin{array}{l}49 \text { patients with CD and } \\
\text { 7I patients with UC. } \\
\text { Include IVF } \pm \text { ICSI + } \\
\text { transfer of FER and fresh } \\
\text { embryos. }\end{array}$ & $\begin{array}{l}\text { Biochemical/ } \\
\text { clinical } \\
\text { pregnancy } \\
\text { after the first } \\
\text { ART cycle }\end{array}$ & $\begin{array}{l}\text { Women with UC: } \\
49.3 \% \\
\text { Women with CD: } \\
42.9 \% \\
\text { Women without } \\
\text { IBD: } 40.9 \% \text {. } \\
\text { No relative risk } \\
\text { estimates were } \\
\text { calculated. } \\
\text { Cohorts were } \\
\text { matched on some } \\
\text { maternal factors } \\
\text { (eg age, parity, } \\
\text { cause of } \\
\text { infertility). }\end{array}$ \\
\hline \multirow[t]{2}{*}{$\begin{array}{l}\text { Nørgård } \\
\text { et al } 2019^{14}\end{array}$} & $\begin{array}{l}\text { Decreased chance of a live born } \\
\text { child in women with rheumatoid } \\
\text { arthritis after assisted } \\
\text { reproduction treatment: } \\
\text { a nationwide cohort study }\end{array}$ & $\begin{array}{l}\text { Cohort } \\
\text { study }\end{array}$ & $\begin{array}{l}\text { Rheumatoid } \\
\text { arthritis }\end{array}$ & $\begin{array}{l}\text { II } 35 \text { embryo transfers in } \\
\text { women with rheumatoid } \\
\text { arthritis. } \\
\text { I97,50I embryo transfers } \\
\text { in women without } \\
\text { rheumatoid arthritis. } \\
\text { Include IVF, with or } \\
\text { without ICSI, and transfer } \\
\text { of FER embryos. }\end{array}$ & $\begin{array}{l}\text { Biochemical } \\
\text { pregnancy } \\
\text { per embryo } \\
\text { transfer }\end{array}$ & $\begin{array}{l}\text { OR } 0.76 \\
(0.65-0.88) \\
\text { aOR } 0.81 \\
(0.68-0.95) c \\
\text { Analyses adjusted } \\
\text { for confounders. }\end{array}$ \\
\hline & & & & $\begin{array}{l}263 \text { embryo transfers in } \\
\text { women with rheumatoid } \\
\text { arthritis. } \\
42,704 \text { embryo transfers } \\
\text { in women without } \\
\text { rheumatoid arthritis. } \\
\text { Include IVF, with or } \\
\text { without ICSI, and transfer } \\
\text { of FER embryos. }\end{array}$ & $\begin{array}{l}\text { Clinical } \\
\text { pregnancy } \\
\text { per embryo } \\
\text { transfer }\end{array}$ & $\begin{array}{l}\text { OR } 0.74 \\
(0.53-1.03) \\
\text { aOR } 0.82 \\
(0.59-1.15)^{c} \\
\text { Analyses adjusted } \\
\text { for confounders. }\end{array}$ \\
\hline \multicolumn{7}{|c|}{ Neurological diseases } \\
\hline $\begin{array}{l}\text { Jølving et al } \\
2020^{15}\end{array}$ & $\begin{array}{l}\text { Live birth in women with } \\
\text { multiple sclerosis receiving } \\
\text { assisted reproduction }\end{array}$ & $\begin{array}{l}\text { Cohort } \\
\text { study }\end{array}$ & $\begin{array}{l}\text { Multiple } \\
\text { sclerosis }\end{array}$ & $\begin{array}{l}932 \text { embryo transfers in } \\
\text { women with multiple } \\
\text { sclerosis. } \\
87,976 \text { embryo transfers } \\
\text { in women without } \\
\text { multiple sclerosis. }\end{array}$ & $\begin{array}{l}\text { Biochemical } \\
\text { pregnancy } \\
\text { per embryo } \\
\text { transfer }\end{array}$ & $\begin{array}{l}\text { OR } 0.88 \\
(0.75-1.03) \\
\text { aOR } 0.92 \\
(0.78-1.08)^{d} \\
\text { Analyses adjusted } \\
\text { for confounders. }\end{array}$ \\
\hline
\end{tabular}

(Continued) 
Table 2 (Continued).

\begin{tabular}{|c|c|c|c|c|c|c|}
\hline $\begin{array}{l}\text { Authorl } \\
\text { Year }\end{array}$ & Title & Design & Disease Area & $\begin{array}{l}\text { Number of Exposed } \\
\text { and Unexposed }\end{array}$ & Outcome & $\begin{array}{l}\text { Key Findings. In } \\
\text { Brackets: the } \\
95 \% \text { Confidence } \\
\text { Interval }\end{array}$ \\
\hline & & & & $\begin{array}{l}315 \text { embryo transfers in } \\
\text { women with multiple } \\
\text { sclerosis. } \\
31,842 \text { embryo transfers } \\
\text { in women without } \\
\text { multiple sclerosis. }\end{array}$ & $\begin{array}{l}\text { Clinical } \\
\text { pregnancy } \\
\text { per embryo } \\
\text { transfer }\end{array}$ & $\begin{array}{l}\text { OR } 0.91 \\
(0.66-1,27) \\
\text { aOR } 0.89 \\
(0.64-1.25)^{\mathrm{d}} \\
\text { Analyses adjusted } \\
\text { for confounders. }\end{array}$ \\
\hline \multirow[t]{2}{*}{$\begin{array}{l}\text { Larsen et al } \\
2020^{16}\end{array}$} & $\begin{array}{l}\text { The efficacy of assisted } \\
\text { reproductive treatment in } \\
\text { women with epilepsy }\end{array}$ & $\begin{array}{l}\text { Cohort } \\
\text { study }\end{array}$ & Epilepsy & $\begin{array}{l}718 \text { ART treatments in } \\
264 \text { women with epilepsy. } \\
\text { I26,884 ART treatments } \\
\text { in } 42,874 \text { women without } \\
\text { epilepsy. }\end{array}$ & $\begin{array}{l}\text { Biochemical } \\
\text { pregnancy } \\
\text { per embryo } \\
\text { transfer }\end{array}$ & $\begin{array}{l}\text { OR I.02 } \\
(0.86-1.22)^{\mathrm{e}} \\
\text { aOR } 1.05 \\
(0.8 \mathrm{I}-1.35)^{\mathrm{f}} \\
\text { Analyses adjusted } \\
\text { for confounders. }\end{array}$ \\
\hline & & & & $\begin{array}{l}26 \text { I ART treatments in } \\
\text { I80 women with epilepsy. } \\
44,97 \text { I ART treatments in } \\
30,724 \text { women without } \\
\text { epilepsy. }\end{array}$ & $\begin{array}{l}\text { Clinical } \\
\text { pregnancy } \\
\text { per embryo } \\
\text { transfer }\end{array}$ & $\begin{array}{l}\text { OR I.04 } \\
(0.72-1.48)^{\mathrm{e}} \\
\text { aOR } 1.55 \\
(0.86-2.78)^{\mathrm{f}} \\
\text { Analyses adjusted } \\
\text { for confounders. }\end{array}$ \\
\hline \multicolumn{7}{|c|}{ Endocrinological diseases } \\
\hline \multirow[t]{3}{*}{$\begin{array}{l}\text { Jølving et al } \\
2019^{17}\end{array}$} & $\begin{array}{l}\text { The chance of a live birth after } \\
\text { assisted reproduction in women } \\
\text { with thyroid disorders }\end{array}$ & $\begin{array}{l}\text { Cohort } \\
\text { study }\end{array}$ & Hyperthyroidism & $\begin{array}{l}1990 \text { embryo transfers in } \\
\text { women with } \\
\text { hyperthyroidism. } \\
192,619 \text { embryo transfers } \\
\text { in women without thyroid } \\
\text { disease. }\end{array}$ & $\begin{array}{l}\text { Biochemical } \\
\text { pregnancy } \\
\text { per embryo } \\
\text { transfer }\end{array}$ & $\begin{array}{l}\text { OR } 0.78 \\
(0.70-0.87) \\
\text { aOR } 0.80 \\
(0.69-0.93)^{c} \\
\text { Analyses adjusted } \\
\text { for confounders. }\end{array}$ \\
\hline & & & & $\begin{array}{l}450 \text { embryo transfers in } \\
\text { women with } \\
\text { hyperthyroidism. } \\
40,955 \text { embryo transfers } \\
\text { in women without thyroid } \\
\text { disease. }\end{array}$ & $\begin{array}{l}\text { Clinical } \\
\text { pregnancy } \\
\text { per embryo } \\
\text { transfer }\end{array}$ & $\begin{array}{l}\text { OR } 0.69 \\
(0.54-0.88) \\
\text { aOR } 0.74 \\
(0.58-0.96)^{c} \\
\text { Analyses adjusted } \\
\text { for } \\
\text { confounders. }\end{array}$ \\
\hline & & & Hypothyroidism & $\begin{array}{l}3613 \text { embryo transfers in } \\
\text { women with } \\
\text { hypothyroidism. } \\
192,619 \text { embryo transfers } \\
\text { in women without thyroid } \\
\text { disease. }\end{array}$ & $\begin{array}{l}\text { Biochemical } \\
\text { pregnancy } \\
\text { per embryo } \\
\text { transfer }\end{array}$ & $\begin{array}{l}\text { OR I.05 } \\
(0.97-1.13) \\
\text { aOR } 1.05 \\
(0.97-1.14)^{c} \\
\text { Analyses adjusted } \\
\text { for confounders. }\end{array}$ \\
\hline
\end{tabular}

(Continued) 
Table 2 (Continued).

\begin{tabular}{|c|c|c|c|c|c|c|}
\hline $\begin{array}{l}\text { Authorl } \\
\text { Year }\end{array}$ & Title & Design & Disease Area & $\begin{array}{l}\text { Number of Exposed } \\
\text { and Unexposed }\end{array}$ & Outcome & $\begin{array}{l}\text { Key Findings. In } \\
\text { Brackets: the } \\
95 \% \text { Confidence } \\
\text { Interval }\end{array}$ \\
\hline & & & & $\begin{array}{l}\text { I24I embryo transfers in } \\
\text { women with } \\
\text { hypothyroidism. } \\
40,955 \text { embryo transfers } \\
\text { in women without thyroid } \\
\text { disease. }\end{array}$ & $\begin{array}{l}\text { Clinical } \\
\text { pregnancy } \\
\text { per embryo } \\
\text { transfer }\end{array}$ & $\begin{array}{l}\text { OR } 0.95 \\
(0.80-1 . I I) \\
\text { aOR } 0.95 \\
(0.81-I .12)^{c} \\
\text { Analyses adjusted } \\
\text { for confounders. }\end{array}$ \\
\hline $\begin{array}{l}\text { Chai et al } \\
2014^{19}\end{array}$ & $\begin{array}{l}\text { Live birth rates following } \\
\text { in vitro fertilization in women } \\
\text { with thyroid autoimmunity and/ } \\
\text { or subclinical hypothyroidism }\end{array}$ & $\begin{array}{l}\text { Cohort } \\
\text { study }\end{array}$ & TAI status & $\begin{array}{l}\text { I } 22 \text { TAI positive women } \\
\text { ( } 89 \text { were euthyroid, } 33 \\
\text { were subclinical } \\
\text { hypothyroid) and } 505 \mathrm{TAI} \\
\text { negative ( } 4 \text { I9 were } \\
\text { euthyroid and } 85 \text { were } \\
\text { subclinical hypothyroid). }\end{array}$ & $\begin{array}{l}\text { Clinical } \\
\text { pregnancy } \\
\text { per fresh } \\
\text { first cycle }\end{array}$ & $\begin{array}{l}\text { In subclinical } \\
\text { hypothyroidism } \\
\text { TAI positive: } \\
42.4 \% \text {. } \\
\text { In euthyroid TAI } \\
\text { positive: } 44.9 \% \text {. } \\
\text { In subclinical } \\
\text { hypothyroidism } \\
\text { TAI negative: } \\
41.9 \% \text {. } \\
\text { In euthyroid TAI } \\
\text { negative: } 45.8 \% \text {. } \\
\text { No relative risk } \\
\text { estimates were } \\
\text { calculated. } \\
\text { No adjustment for } \\
\text { confounding. }\end{array}$ \\
\hline \multirow[t]{3}{*}{$\begin{array}{l}\text { Larsen et al } \\
2020^{20}\end{array}$} & $\begin{array}{l}\text { Live-born children after assisted } \\
\text { reproduction in women with } \\
\text { type I diabetes and type } 2 \\
\text { diabetes: a nationwide cohort } \\
\text { study }\end{array}$ & $\begin{array}{l}\text { Cohort } \\
\text { study }\end{array}$ & $\begin{array}{l}\text { Diabetes } \\
\text { Mellitus type I }\end{array}$ & $\begin{array}{l}532 \text { embryo transfers in } \\
180 \text { women with type I } \\
\text { diabetes, and } 126,113 \\
\text { embryo transfers in } \\
42,626 \text { women without } \\
\text { diabetes. }\end{array}$ & $\begin{array}{l}\text { Biochemical } \\
\text { pregnancy } \\
\text { per embryo } \\
\text { transfer }\end{array}$ & $\begin{array}{l}\text { OR I.I0 } \\
(0.90-1.35) \\
\text { aOR I.00 } \\
(0.79-1.26)^{\mathrm{g}} \\
\text { Analyses adjusted } \\
\text { for confounders. }\end{array}$ \\
\hline & & & & $\begin{array}{l}200 \text { embryo transfers in } \\
\text { I } 36 \text { women with type I } \\
\text { diabetes, and } 44,73 \text { I } \\
\text { embryo transfers in } \\
30,4 \mid 7 \text { women without } \\
\text { diabetes. }\end{array}$ & $\begin{array}{l}\text { Clinical } \\
\text { pregnancy } \\
\text { per embryo } \\
\text { transfer }\end{array}$ & $\begin{array}{l}\text { OR I.I2 } \\
(0.74-1.69) \\
\text { aOR I.36 } \\
(0.8 I-2.29)^{g} \\
\text { Analyses adjusted } \\
\text { for confounders. }\end{array}$ \\
\hline & & & $\begin{array}{l}\text { Diabetes } \\
\text { Mellitus Type } 2\end{array}$ & $\begin{array}{l}513 \text { embryo transfers in } \\
173 \text { women with type } 2 \\
\text { diabetes, and } 126,113 \\
\text { embryo transfers in } \\
42,626 \text { women without } \\
\text { diabetes. }\end{array}$ & $\begin{array}{l}\text { Biochemical } \\
\text { pregnancy } \\
\text { per embryo } \\
\text { transfer }\end{array}$ & $\begin{array}{l}\text { OR } 0.56 \\
(0.44-0.70) \\
\text { aOR } 0.57 \\
(0.43-0.76)^{g} \\
\text { Analyses adjusted } \\
\text { for confounders. }\end{array}$ \\
\hline
\end{tabular}

(Continued) 
Table 2 (Continued).

\begin{tabular}{|c|c|c|c|c|c|c|}
\hline $\begin{array}{l}\text { Authorl } \\
\text { Year }\end{array}$ & Title & Design & Disease Area & $\begin{array}{l}\text { Number of Exposed } \\
\text { and Unexposed }\end{array}$ & Outcome & $\begin{array}{l}\text { Key Findings. In } \\
\text { Brackets: the } \\
95 \% \text { Confidence } \\
\text { Interval }\end{array}$ \\
\hline & & & & $\begin{array}{l}131 \text { embryo transfers in } \\
89 \text { women with type } 2 \\
\text { diabetes, and } 44,73 \text { I } \\
\text { embryo transfers in } \\
30,417 \text { women without } \\
\text { diabetes. }\end{array}$ & $\begin{array}{l}\text { Clinical } \\
\text { pregnancy } \\
\text { per embryo } \\
\text { transfer }\end{array}$ & $\begin{array}{l}\text { OR } 0.72 \\
(0.45-1.15) \\
\text { aOR } 0.91 \\
(0.50-1.66)^{g} \\
\text { Analyses adjusted } \\
\text { for confounders. }\end{array}$ \\
\hline
\end{tabular}

Notes: a Matched according to oocyte age at retrieval, body mass index, anti-Müllerian hormone, and basal antral follicle count. ${ }^{b}$ Extended model using data from 2006, adjusted for: Charlson Index, women's age, calendar year of treatment, type of treatment (IVF, ICSI, FER), cause of infertility (female factor, male factor, or mixture of factors/ idiopathic), body mass index, partner's age, smoking at the time of embryo transfer, and alcohol. 'Adjusted for Charlson Index, women's age, calendar year of treatment, type of treatment (IVF, ICSI, FER), cause of infertility (female factor, male factor, or mixture of factors/idiopathic). 'Adjusted for comorbidity, women's age, calendar year of

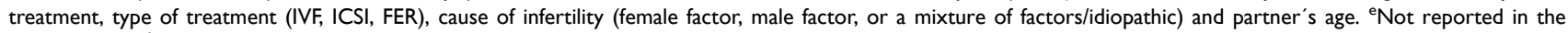
original paper. 'Adjusted for women's age, calendar year of treatment, cause of infertility (female factor, male factor, or mixture of factors/idiopathic), body mass index, smoking and alcohol. ' ${ }^{g}$ Adjusted for women's age, calendar year of treatment, cause of infertility (female factor, male factor, or a mixture of factors/idiopathic), body mass index, smoking at the time of embryo transfer and alcohol.

Abbreviations: ART, assisted reproductive technology; CD, Crohn's disease; FER, frozen-thawed embryos; IBD, inflammatory bowel disease; IVF, in vitro fertilization; ICSI, intracytoplasmic sperm injection; OR, crude odds ratio; aOR, adjusted odds ratio; TAI, thyroid autoimmunity; UC, ulcerative colitis.

a decreased chance of live birth within 18 months (adjusted OR 0.29, 95\% CI: 0.13 to 0.65 ).

In a matched cohort study from 2020, Hernandez-Nieto et al examined the efficacy of in vitro fertilization based on a study population where all fresh transfers were excluded, and all embryos had been examined via preimplantation genetic diagnosis for abnormal numbers of chromosomes. ${ }^{10}$ One of the study outcomes was live birth, and based on 38 patients with inflammatory bowel diseases and 114 controls, the study found a decreased chance of live birth (OR 0.80, 95\% CI: 0.03 to 20.54). Due to the small number of embryo transfers, the statistical precision was very low.

The chance of a biochemical/clinical pregnancy after ART has also been studied. ${ }^{8,10}$ Friedman et al suggested that, compared to other women receiving ART, women with inflammatory bowel diseases had a reduced chance of conceiving after ART treatment cycles, and the adjusted OR of a biochemical/clinical pregnancy in women with ulcerative colitis and Crohn's disease was 0.67 (95\% CI: 0.53 to 0.84 ) and 0.75 (95\% CI: 0.51 to 1.10), respectively, Table $2 .^{8}$ Friedman et al also analyzed the chance of live birth in the subgroup of women with a positive biochemical/clinical pregnancy and the result was similar between women with ulcerative colitis, and Crohn's disease and the unexposed cohort, adjusted OR 1.16 (95\% CI: 0.75 to 1.79 ), and 0.89
(95\% CI: 0.44 to 1.83 ) (Table 1). The study from Hernandez-Nieto et al also found a decreased chance of implantation and clinical pregnancy, OR $0.68(95 \%$ CI: 0.3 to 1.5$)$ and 0.68 (95\% CI: 0.2 to 1.8$)$, respectively. ${ }^{10}$

The impact of corticosteroid treatment in patients with chronic inflammatory bowel diseases has not been settled. A study on this subject was published in 2020 but was not included as part of selected papers for this review as the analyses did not use an external control group, but compared live births in women with chronic inflammatory bowel disease receiving corticosteroids to women with chronic inflammatory bowel disease not receiving corticosteroids. $^{31}$ The study found that the adjusted OR for live birth in women with Crohn's disease receiving corticosteroids before embryo transfer, relative to women with Crohn's disease not receiving corticosteroids, was 0.89 (95\% CI: 0.49 to 1.63 ), and the corresponding result in ulcerative colitis was 0.98 (95\% CI: 0.55 to 1.74$)$.

\section{Conclusion}

The largest data sets, and the results with best statistical precision, originate from Denmark. These studies were based on nationwide health registries widely used for valid clinical epidemiological research. ${ }^{32-34}$ Based on different analytic approaches (per cycle analyses and per women analyses) the results suggested that the chance of live birth 
after ART treatment in women with ulcerative colitis and Crohn's disease was reduced, compared to other women receiving ART. These studies also suggested that former surgery for Crohn's disease significantly reduced the chance of a live birth. The analyses on biochemical/clinical pregnancy suggest that the reduced chance of live birth might be related to the stages of implantation, and not the ability to carry the child to term. The sum of evidence on these different ART outcomes, and an impact of disease activity and medication, is however still sparse.

\section{The Efficacy of ART in Women with Rheumatoid Arthritis}

The relevance for studying the success after ART in women with rheumatoid arthritis is important for a number of reasons: i) the number of women with rheumatoid arthritis during the fertile years is increasing, ${ }^{6}$ ii) earlier studies have suggested that a high proportion of women with rheumatoid arthritis were childless compared to references and that the relative fertility rate was reduced after the diagnosis of rheumatoid arthritis (relative fertility rate 0.88 (95\% CI: 0.84 to 0.93$)),{ }^{35}$ and iii) women with rheumatoid arthritis have been found to be more likely to seek help from ART compared to references. ${ }^{36}$

\section{The Chance of a Live Born Child, Biochemical Pregnancy, and Clinical Pregnancy in Women with Rheumatoid Arthritis}

In a nationwide study, a total of 1149 ART treatments in women with rheumatoid arthritis were examined together with 198,941 ART treatments in women without rheumatoid arthritis. ${ }^{14}$ Among embryo transfers in patients with rheumatoid arthritis, the median duration of rheumatoid arthritis at the time of embryo transfer was 82 months (25-75\% percentiles: $42-134$ months). There were 208 live births (18.1\%) per embryo transfer in women with rheumatoid arthritis, and 47,077 live births $(23.7 \%)$ in women without rheumatoid arthritis. The adjusted OR for an ART treatment in women with rheumatoid arthritis leading to a live birth, compared to ART treatments in women without rheumatoid arthritis, were significantly reduced 0.78 (95\% CI: 0.65 to 0.92 ), Table 1 . The impact of prescription of corticosteroids 3 months prior to embryo transfer was also examined, and the adjusted OR of live birth was 1.32 (95\% CI: 0.85 to
2.05), Table 1. Restricting the time period for prescription of corticosteroid to only one month prior to embryo transfer, the adjusted OR for live birth in women with rheumatoid arthritis was 1.83 (95\% CI: 1.07 to 2.37 ), compared to women with rheumatoid arthritis who did not have a prescription of corticosteroid. The study also reported that the chance of a biochemical pregnancy after embryo transfer, and the adjusted chance of a positive hCG in women with rheumatoid arthritis, relative to women without rheumatoid arthritis, was significantly reduced, adjusted OR 0.81 (95\% CI: 0.68 to 0.95$)$. The analyses on the chance of a clinical pregnancy showed similar results adjusted OR 0.82 (95\% CI: 0.59 to 1.15$)$, Table 2 .

\section{Conclusion}

The evidence on the efficacy of ART treatment on women with rheumatoid arthritis is indeed weak. Only one study has thus examined the chance of a live born child in women with rheumatoid arthritis receiving ART treatment, compared to other women receiving ART. ${ }^{14}$ The study suggested that ART treatments in women with rheumatoid arthritis had a significantly decreased chance of a live birth per embryo transfer, compared to ART treatments in women without rheumatoid arthritis. The results also suggested that the reason might be related to a decreased chance of implantation of the embryo (decreased chance of a biochemical and clinical pregnancy). The results did not reveal whether the decreased chance of live birth was related to the disease itself or to factors closely related to rheumatoid arthritis such as disease activity and/or the medications used to treat rheumatoid arthritis. There is an obvious need for other studies addressing these factors.

\section{The Efficacy of ART in Women with Multiple Sclerosis}

Multiple sclerosis is one of the most common neurological demyelinating diseases and is predominant in women with a peak incidence during the childbearing years from ages $20-45^{37,38}$ Whether fertility is impaired in multiple sclerosis is still debated. ${ }^{39-42}$ Previous studies related to ART have focused on multiple sclerosis symptoms, and the disease course during ART treatment, and a number of putative mechanisms involved in multiple sclerosis have been suggested to worsen after ART treatment resulting in an increased relapse rate of symptoms. ${ }^{39,43-45}$ 


\section{The Chance of a Live Born Child,} Biochemical Pregnancy, and Clinical Pregnancy in Women with Multiple Sclerosis

In a nationwide Danish cohort study from 2020, a total of 2267 embryo transfers in women with multiple sclerosis were compared to 200,684 embryo transfers in women without multiple sclerosis. ${ }^{15}$ Data showed a median duration of multiple sclerosis at the time of embryo transfer of 18 years (25-75 percentile; 9-26 years). A total of $22 \%$ of the embryo transfers in women with multiple sclerosis resulted in a live born child, compared to $24 \%$ in women without multiple sclerosis (Table 1). The adjusted OR of a live birth was 0.91 (95\% CI: 0.81 to 1.02 ). The study also included an analysis of the potential impact of corticosteroid prior to embryo transfer, and the adjusted OR of a live birth in women with multiple sclerosis having prescription of corticosteroid prior to embryo transfer was 0.90 (95\% CI: 0.49 to 1.68 ), compared to women with multiple sclerosis receiving no prescription of corticosteroids (Table 1).

The study also analyzed a positive hCG and a clinical pregnancy as outcome measurements. The adjusted OR of a positive hCG measurement in women with multiple sclerosis, relative to women without multiple sclerosis, was 0.92 (95\% CI: 0.78 to 1.08 ), and the adjusted OR for a clinical pregnancy in women with multiple sclerosis was 0.89 (95\% CI: 0.64 to 1.25 ) (Table 2).

\section{Conclusion}

Only one study has examined the chance of live birth in women with multiple sclerosis receiving ART treatment, ${ }^{15}$ and therefore the evidence is indeed weak in these women. The study suggested a decreased chance (although not statistically significantly decreased) of a live birth in women with multiple sclerosis receiving ART treatment compared to other women receiving ART treatment. The use of corticosteroids up to 3 months before embryo transfer did not seem to have a positive impact on the chance of a live birth. A possible beneficial impact of corticosteroids on embryo implantation in women with multiple sclerosis is however uncertain and a beneficial impact on ART treatment in general is still discussed. ${ }^{46}$ Others have hypothesized that use of corticosteroids in women undergoing ART treatment is associated with an increased pregnancy rate, suggesting that amongst some women there may be subsets with undiagnosed immune disorders that benefit from immunosuppressive therapy. ${ }^{46,47}$

\section{The Efficacy of ART in Women with Epilepsy}

Epilepsy is another relatively common chronic disease seen in women during the childbearing years. ${ }^{6}$ In general, epilepsy is not regarded as an autoimmune disease but accumulating evidence suggests a role for inflammation in the pathophysiology of epilepsy, and key preclinical and clinical findings now support a role for brain inflammation in the pathogenesis of seizures. ${ }^{48-50}$ Different reproductive issues have been examined in women with epilepsy, for instance, birth rates and voluntary childlessness. The birth rates among women with epilepsy have been found to be lower than in the general population. $^{51-53}$ and birth rates could be lower in these women for several reasons, such as social factors eg lower marriage rates or women might decide not to have children because of their epilepsy. ${ }^{54}$ The efficacy of ART in women with epilepsy has however not been a general subject of interest.

\section{The Chance of a Live Born Child, Biochemical Pregnancy, and Clinical Pregnancy in Women with Epilepsy}

A nationwide Danish study examined 730 ART treatments in 264 women with a history of epilepsy, compared to 128,387 ART treatments in women without a history of epilepsy. ${ }^{16}$ In the exposed cohort, $62.6 \%$ had reimbursed prescriptions of anti-epileptic drugs within one year before the date of embryo transfer. In women with epilepsy, $24.7 \%$ of the embryo transfers resulted in a live born child, versus $23.9 \%$ in women without epilepsy (Table 1). The crude and adjusted ORs for an embryo transfer in women with epilepsy leading to a live birth, compared to embryo transfer in women without epilepsy, were 1.03 (95\% CI: 0.86 to 1.25 ) and 1.06 (95\% CI: 0.88 to 1.28 ), respectively. The adjusted OR for live birth among users of anti-epileptic drugs was 1.22 (95\% CI: 0.77 to 1.92), relative to women who had stopped the use of anti-epileptic drugs prior to embryo transfer. An impact of corticosteroids prior to embryo transfer was not studied.

The adjusted OR of a biochemical pregnancy after embryo transfer in women with epilepsy, relative to women without epilepsy, was 1.05 (95\% CI: 0.81 to 1.35), and the adjusted OR for a clinical pregnancy after embryo transfer in women with epilepsy was 1.55 (95\% CI: 0.86 to 2.78 ), Table 2 . 


\section{Conclusion}

The study published in 2020 is the only study that has examined the efficacy of ART in women with epilepsy and a potential impact of anti-epileptic drugs. The study suggests that the chance of a live birth per embryo transfer was similar in women with and without epilepsy. Regarding an impact of anti-epileptic drugs, it was reassuring that the use of these medications did not seem to reduce the chance of a live born child. The main limitations of the study were that it was not possible to perform sub-analyses according to severity of epilepsy or according to different types of epilepsy. There is an obvious need for more studies within this area.

\section{The Efficacy of ART in Women with Thyroid Disease}

It is known that thyroid disorders may adversely affect female fertility in various ways by leading to anovulatory cycles, luteal phase defect, high prolactin levels, and sex hormone imbalances, ${ }^{55,56}$ all of which may cause both infertility and adverse pregnancy outcomes. ${ }^{57-59}$ The impact of subclinical hypothyroidism, thyroid autoimmunity and medical treatment of thyroid disorders on ART efficacy has been studied according to outcomes such as miscarriage, clinical pregnancy and live birth rates. ${ }^{17,19,60-69}$

\section{The Chance of a Live Born Child, Biochemical Pregnancy, and Clinical Pregnancy in Women with Thyroid Disease}

Concerns about the impact of thyroid autoimmunity as a potential consequence of subclinical hypothyroidism, which is closely related to hypothyroidism, have been addressed in two papers. In 2014, a study by Chai et al examined the live birth rate, and the clinical pregnancy rate, following IVF. $^{19}$ The study population included 125 women with positive thyroid autoimmunity, and 511 women with negative thyroid autoimmunity. No patients in these groups had clinical hypothyroidism. In those with positive thyroid autoimmunity, 33 women had subclinical hypothyroidism and the live birth proportion per fresh cycle was $33.3 \%$. In those with negative thyroid autoimmunity, 86 had subclinical hypothyroidism and the live birth proportion per fresh cycle was $36.0 \%$ (Table 1). The proportions who obtained a clinical pregnancy per cycle were also similar between the groups (Table 2). The study was mainly descriptive with no confounder control. A study by Unuane et al from 2016 examined the live birth rate in thyroid autoimmunity positive women $(\mathrm{n}=333)$, compared to women with negative thyroid autoimmunity $(n=2019) .{ }^{18}$ The analyses were restricted to live birth after 25 weeks of gestation. All patients received standard IVF treatments with up to six treatment cycles. The crude cumulative delivery proportion after six cycles was $47 \%$ in those with, and without, positive thyroid autoimmunity (Table 1). The authors refer to a Cox regression analysis including a number of important thyroid-related variables and clinical variables and conclude that only female age had a significant impact on delivery rate. The risk estimates were not presented in the paper, and the authors did not report on the chance of a biochemical or clinical pregnancy. In a nationwide cohort study from 2019, the efficacy of ART treatment was studied in women diagnosed with hyperthyroidism and hypothyroidism prior to embryo transfer. ${ }^{17}$ The outcomes studied were live birth, biochemical pregnancy and clinical pregnancy. ${ }^{17}$ A total of 2010 embryo transfers in women with hyperthyroidism, and 3692 embryo transfers in women with hypothyroidism, were included, and compared to 193,972 embryo transfers in women without thyroid diseases. A total of $19.30 \%$ of the women with hyperthyroidism had a live born child per embryo transfer, and $24.08 \%$ of the women without thyroid diseases, corresponding to an adjusted OR of 0.86 (95\% CI: 0.76 to 0.98 ). A total of $23.56 \%$ of the women with hypothyroidism had a live born child per embryo transfer, and the chance of a live birth in women with hypothyroidism, compared to women without thyroid diseases, was close to unity (adjusted OR 1.03, 95\% CI: 0.94 to 1.12) (Table 1). In women with hyperthyroidism, the adjusted OR of a biochemical pregnancy was $0.80(95 \%$ CI: 0.69 to 0.93 ), and the adjusted OR of a clinical pregnancy was 0.74 (95\% CI: 0.58 to 0.96 ) (Table 2). In women with hypothyroidism, the chance of a biochemical pregnancy and clinical pregnancy was not decreased, adjusted OR 1.05 (95\% CI: 0.97 to 1.14 ) and 0.95 (95\% CI: 0.81 to 1.12 ), respectively.

\section{Conclusion}

Based on the results from two, mainly descriptive, papers, thyroid autoimmunity and subclinical hypothyroidism did not seem to impair the live birth rates. A large study from 2019 suggested that women diagnosed with hyperthyroidism had a significantly decreased chance of 
a live birth per embryo transfer, compared to embryo transfers in women without thyroid disorders. Also, a reduced chance of a biochemical and a clinical pregnancy indicated that the problems might be related to inadequate implantation or early development of the embryo in the uterus. On the contrary, the chance of a live birth after embryo transfer in women with hypothyroidism was comparable to women without thyroid diseases undergoing ART treatment. In Denmark, all female infertility patients are routinely screened for thyroid disorders with measurements of thyroid-stimulating hormone levels at all fertility clinics during the past 5-10 years and relevant medication is introduced prior to the infertility treatment. It is well known that biomarkers including thyroid antibodies, thyroid-stimulating hormone, thyroxine, etc., may play an important role on reproductive outcomes. However, the nationwide Danish study from 2019 had no access to examine the potential impact of biomarkers, and did not have information on the etiology of the thyroid disease. Future studies must be performed to understand the mechanisms behind a possible decreased chance of a live birth in women with hyperthyroidism, and to study the details related to disease severity, medications, thyroid hormone levels, and antibodies.

\section{The Efficacy of ART in Women with Type I and Type 2 Diabetes Mellitus}

The state of autoimmunity is well known in type 1 diabetes, ${ }^{70,71}$ and type 2 diabetes is associated with metabolic traits like polycystic ovary syndrome, obesity, insulin resistance and chronic inflammation. In general, both type 1 and type 2 diabetes are associated with a number of reproductive problems including reduced fertility, early and late pregnancy loss, congenital malformations, vascular stress, hypertensive disorders in pregnancy, preterm labor, and infections. ${ }^{72-75}$ The efficacy of ART treatment in women with diabetes was first examined in $2020 .{ }^{20} \mathrm{An}$ impact of female body mass index had been studied in relation to ART, but the results did not include information on diabetes. ${ }^{76}$

\section{The Chance of a Live Born Child,} Biochemical Pregnancy, and Clinical Pregnancy in Women with Diabetes

In a nationwide Danish cohort study, 187 women with type 1 diabetes and 170 women with type 2 diabetes, having
538 and 518 embryo transfers, respectively, were identified. ${ }^{20}$ The unexposed cohort compromised 127,599 embryo transfers in 42,688 women without a history of diabetes before embryo transfer. A total of $26.4 \%$ of the women with type 1 diabetes had a live born child per transfer, and this was similar to the unexposed cohort $(23.9 \%)$, and corresponding to an adjusted OR of 1.10 (95\% CI: 0.86 to 1.41 ) (Table 1). Only $13.5 \%$ of the women with type 2 diabetes had a live born child after embryo transfer, and the chance of live birth was significantly reduced compared to the unexposed cohort, adjusted OR 0.50 (95\% CI: 0.36 to 0.71 ) (Table 1). In women with type 2 diabetes, stratified analyses were performed according to normal weight and overweight-obesity. The result showed that women with normal weight had a reduced chance for a live born child, adjusted OR of 0.37 (95\% CI: 0.16 to 0.85 ), and women with overweightobesity also had a reduced chance of a live born child, adjusted OR of 0.52 (95\% CI: 0.36 to 0.77$).{ }^{20}$ These results included an adjustment for maternal age.

In women with type 1 diabetes undergoing ART treatment, the chance of a biochemical pregnancy and clinical pregnancy was not decreased, adjusted OR 1.00 (95\% CI: 0.79 to 1.26$)$ and 1.36 (95\% CI: 0.81 to 2.29$)$, respectively (Table 2). ${ }^{20}$ In women with type 2 diabetes, the adjusted OR of a biochemical pregnancy was 0.57 (95\% CI: 0.43 to $0.76)$, and the adjusted OR of a clinical pregnancy was 0.91 (95\% CI: 0.50 to 1.66$).{ }^{20}$

\section{Conclusion}

The evidence on the efficacy of ART in women with type 1 and 2 diabetes is indeed sparse. Only one study based on nationwide data has examined the efficacy of ART when it comes to a live born child, biochemical and clinical pregnancy per embryo transfer. The study suggested that women with type 2 diabetes had a significantly decreased chance of live birth per embryo transfer, compared with ART treatments in women without diabetes, and the data suggested that the reason was related to decreased chance of implantation of the embryo. The findings in women with type 2 diabetes did not seem to be driven by obesity per se as similar results were seen in both normal-weight and obese women. Women with type 1 diabetes had an equivalent chance of a live birth per embryo transfer compared to women without diabetes. The data did not include information on glycated hemoglobin test (HbA1c) and it cannot be ruled out that women with type 2 diabetes had worse glycemic control than women with type 1 
diabetes. Prospective studies including characterization of anthropometrics, glucose and lipid metabolism, treatment at the time of ART and biomarkers markers of chronic inflammation should be performed to confirm the findings in other settings and to address the underlying mechanisms for the findings.

\section{Discussion Overall Findings}

This review draws attention to the still underexplored area regarding the efficacy of ART treatment in women with different chronic diseases, and whether they can expect the same success after ART as other women in the general population receiving ART. The review highlights the lack of evidence in this area. A paper from 2019 examined very broad categories of women with chronic diseases and found lower odds of a live birth, compared to healthy women. ${ }^{9}$ The study included 1291 women receiving ART and the underlying diseases for these women were distributed across all ICD10 categories. The studies included in this review points towards a more varied and complex picture. In women with ulcerative colitis, Crohn's disease, rheumatoid arthritis, multiple sclerosis, hyperthyroidism, and type 2 diabetes the results, included in the review, suggested a decreased chance of a live birth per embryo transfer, compared to embryo transfers in other women undergoing ART (although not statistically significantly decreased in multiple sclerosis). On the contrary, based on this review, initial results on women with hypothyroidism, type 1 diabetes and epilepsy indicated that these women had an equivalent chance of a live birth per embryo transfer compared to other women undergoing ART. Some papers also studied the chance of early successful implantation (biochemical pregnancy/clinical pregnancy), and the general picture was that for those diseases, for which a decreased chance of a live birth was suggested, the chance of biochemical pregnancy/clinical pregnancy was also decreased. These results thus indicated that the problems might be related to inadequate implantation or early development of the embryo, and not related to the chance of carrying the child throughout the pregnancy until birth.

The most methodologic robust studies within this area derived from Denmark, and the main advantages were that they were based on nationwide data, they included unselected study cohorts, and it was possible to adjust for several important confounders. They typically controlled for Charlson's comorbidity index, women's age, calendar year of ART treatment, type of ART treatment, cause of infertility, maternal smoking, and in some studies also for body mass index, medications, partner's age, smoking at the time of embryo transfer, and alcohol. On the other hand, the main limitations were lack of detailed information on the severity of disease, disease activity, other clinical details, and laboratory values.

\section{Mechanisms Behind the Findings}

The chance of a live born child after ART is affected by numerous factors related to the different stages of fertilization, implantation and to the ability to maintain a pregnancy throughout the trimesters. In general, one of the most important limiting factors in achieving a pregnancy in ART treatment is the low implantation rate, and poor endometrial receptivity is considered one of the main causes of implantation failure. ${ }^{77-79}$ Endometrial receptivity and implantation are complex processes involving factors such as the immune system, cytokines, hormones, proteomics, metabolomics and the quality of the embryo itself. Implantation requires successful establishment of immunologic tolerance towards the implanting embryo and this mechanism is not yet fully understood. ${ }^{80,81}$ It has, however, in recent years become apparent that it involves cross talk between the embryo and the maternal immune system, mediated by a variety of biological factors, and implantation is increasingly recognized as an inflammatory process, requiring regulation of inflammatory pathways. ${ }^{80,82-84}$ Seen in this perspective, it is therefore not surprising that women with some autoimmune and chronic inflammatory diseases have a decreased chance of implantation or early development of the embryo. A relevant question is however why we see a decreased chance in some autoimmune diseases and not in others. For instance, it is not easily explained why we find a decreased chance of a biochemical pregnancy in women with type 2 diabetes and in hyperthyroidism, but not in type 1 diabetes and hypothyroidism. These diseases are characterized by autoimmunity and/or chronic inflammation, but still there must be important factors that we have no data on (including how well the chronic diseases are medically regulated, the level of inflammation, presence of endometritis, impact of inflammatory parameters, impact of medication, etc.). Some evidence has suggested a role of inflammation in the pathophysiology of epilepsy, ${ }^{48}$ but in general epilepsy is not regarded as an autoimmune disease, and based on this is not surprising 


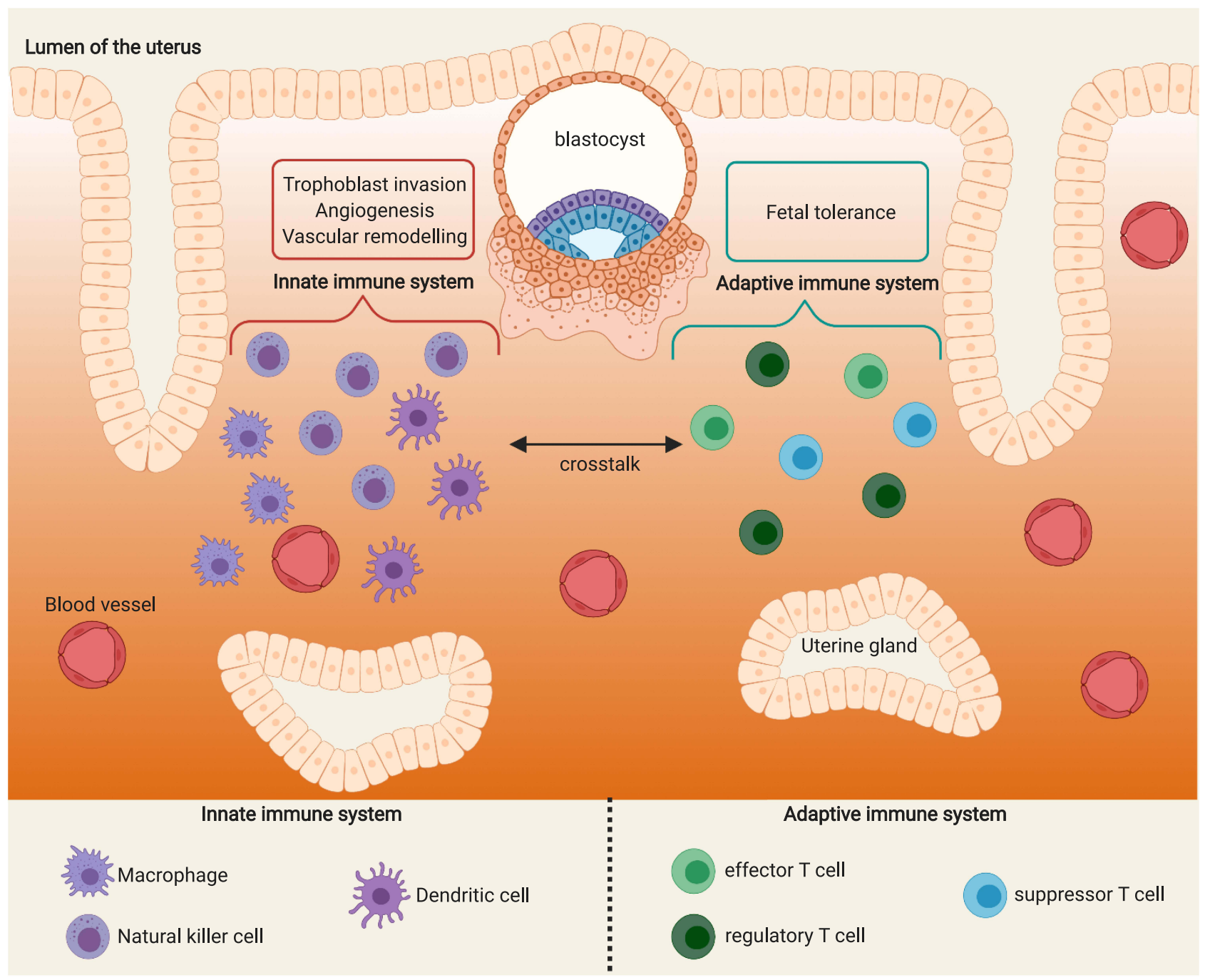

Figure 3 Possible underlying mechanisms that might explain differences in ART efficacy across women with different chronic diseases. Created with BioRender.com.

that the efficacy of ART in women with epilepsy was comparable to other women receiving ART treatment.

A possible explanation behind these differences could reside in the disease-specific dysregulation of the innate or adaptive immune system (Figure 3). Indeed, immunological diseases can be described as autoimmune, autoinflammatory, or a combination of both. ${ }^{85}$ Briefly, autoimmune diseases are triggered by the dysfunctional activation of the adaptive immune system causing tissue destruction by self-reacting $\mathrm{B}$ and $\mathrm{T}$ lymphocytes, while in autoinflammatory diseases, it is the innate immune system that selfreacts, damaging the surrounding tissues. ${ }^{86}$ Interestingly, ulcerative colitis, Crohn's disease, type 2 diabetes, and rheumatoid arthritis all have a strong autoinflammatory component, ${ }^{85-87}$ while, for example, type 1 diabetes is mainly a $\mathrm{T}$ cell-driven chronic disease. ${ }^{88}$ The discussion is more complicated when dealing with the difference observed between hypothyroidism and hyperthyroidism. Indeed, it is known that there is a crosstalk between thyroid hormones and the immune system, both innate and adaptive, but this relationship is complex and further investigation is still necessary to fully understand it. However, it seems that a proinflammatory response is stimulated by hyperthyroidism. ${ }^{89}$ Moreover, before starting fertility treatment, women with hypothyroidism receive thyroid hormone replacement therapy to normalize thyroid hormone levels and this could help their pregnancy success rate.

Based on the data included in this review, it could be hypothesized that the effect of chronic inflammation caused by a dysfunctional innate immune system has a higher impact on the implantation process. Indeed, 
cells of the innate immune system, especially macrophages, natural killers, and dendritic cells, represent the largest percentage of leukocytes present in the endometrium during the implantation phase. They have a fundamental role in regulating angiogenesis, vascular remodeling, and trophoblast invasion. Instead, effector, regulatory, and suppressor $\mathrm{T}$ cells from the adaptive immune system are involved in the immune tolerance toward the semi-allogeneic fetus and they are partially modulated and activated by the innate immune system..$^{90}$

Several anti-inflammatory and immunosuppressive drugs have been tested to find effective therapies to improve embryo implantation but it is still an ongoing debate whether corticosteroid drugs such as prednisolone can be used with beneficial effect in ART treatment. ${ }^{46,91}$ A strictly controlled immune system is fundamental for a successful pregnancy but the idea of pregnancy as an immunosuppressive state is restrictive. Indeed, during pregnancy, the immune system goes through different inflammatory and anti-inflammatory phases. ${ }^{92}$ Excessive immunosuppression could be deleterious so corticosteroid administration might be helpful only in a specific group of patients and with specific treatment protocols.

\section{Conclusion and Perspectives}

We favor a scenario where we are able to address and understand numerous reproductive issues when we consult with patients, but still we are left with a variety of unanswered questions, for instance, the relevance of special ART treatment programs for patients with different kinds of underlying diseases. ${ }^{93}$ A multidisciplinary clinical approach is necessary to advise each individual woman to determine the best decisions in a complex scenario of interconnected factors. The studies included in this review only give some initial answers regarding the efficacy of ART in women with different underlying diseases. Our results indicate that women with some autoimmune and chronic inflammatory diseases have problems with a low implantation rate or early development of the embryo in ART and our results indeed call for further studies. Critical factors to be examined could relate to the diseases themselves and their treatments (eg underlying state of inflammation, disease activity, and medical treatments to control the disease and disease activity), endometrial receptivity, changes in the endometrial cytokines, abnormal reproductive hormones, or other factors. ${ }^{94-97}$ Studies on the effect of innate and adaptive immune system dysregulation during implantation and pregnancy should be conducted, and it would be valuable to perform new randomized controlled studies to evaluate the effect of corticosteroids on ART treatments. Preferably, there should be more focus on timing and corticosteroid dosage, biomarkers for disease activity, immune system functionality, and endometrial receptivity.

\section{Ethics}

This paper does not raise any ethical concerns.

\section{Author Contributions}

All authors contributed to data analyses/interpretations, drafting or revising the article, have agreed on the journal to which the article will be submitted, gave final approval of the version to be published, and agreed to be accountable for all aspects of the work.

\section{Funding}

There is no funding to report.

\section{Disclosure}

The authors reported no conflicts of interest for this work.

\section{References}

1. Schmidt L. Infertility and assisted reproduction in Denmark. Epidemiology and psychosocial consequences. Dan Med J. 2006;53 (4):390-417.

2. Henningsen AA, Gissler M, Skjaerven R, et al. Trends in perinatal health after assisted reproduction: a Nordic study from the CoNARTaS group. Hum Reprod. 2015;30(3):710-716. doi:10.1093/humrep/ deu345

3. Nyboe Andersen A, Erb K. Register data on Assisted Reproductive Technology (ART) in Europe including a detailed description of ART in Denmark. Int $J$ Androl. 2006;29(1):12-16. doi:10.1111/j.13652605.2005.00577.x

4. De Geyter C, Calhaz-Jorge C, Kupka MS, et al. ART in Europe, 2014: results generated from European registries by ESHRE: the European IVF-monitoring Consortium (EIM) for the European Society of Human Reproduction and Embryology (ESHRE). Hum Reprod. 2018;33(9):1586-1601. doi:10.1093/humrep/dey242

5. Pinborg A, Loft A, Romundstad LB, et al. Epigenetics and assisted reproductive technologies. Acta Obstet Gynecol Scand. 2016;95 (1):10-15. doi:10.1111/aogs.12799

6. Jolving LR, Nielsen J, Kesmodel US, Nielsen RG, Beck-Nielsen SS, Norgard BM. Prevalence of maternal chronic diseases during pregnancy - a nationwide population based study from 1989 to 2013. Acta Obstet Gynecol Scand. 2016;95(11):1295-1304. doi:10.1111/ aogs. 13007

7. Oza SS, Pabby V, Dodge LE, et al. In vitro fertilization in women with inflammatory bowel disease is as successful as in women from the general infertility population. Clin Gastroenterol Hepatol. 2015;13 (9):1641-1646. doi:10.1016/j.cgh.2015.03.016

8. Friedman S, Larsen PV, Fedder J, Norgard BM. The reduced chance of a live birth in women with IBD receiving assisted reproduction is due to a failure to achieve a clinical pregnancy. Gut. 2017;66(3):556-558. doi:10.1136/gutjnl-2016-311805 
9. Tarin JJ, Pascual E, Garcia-Perez MA, Gomez R, Cano A. Women's morbid conditions are associated with decreased odds of live birth in the first IVF/ICSI treatment: a retrospective single-center study. J Assist Reprod Genet. 2019;36(4):697-708. doi:10.1007/s10815019-01401-4

10. Hernandez-Nieto C, Sekhon L, Lee J, Gounko D, Copperman A, Sandler B. Infertile patients with inflammatory bowel disease have comparable in vitro fertilization clinical outcomes to the general infertile population. Gynecol Endocrinol. 2020;36(6):554-557. doi:10.1080/09513590.2019.1684465

11. Friedman S, Larsen PV, Fedder J, Norgard BM. The efficacy of assisted reproduction in women with inflammatory bowel disease and the impact of surgery-A nationwide cohort Study. Inflamm Bowel Dis. 2017;23 (2):208-217. doi:10.1097/MIB.0000000000000996

12. Norgard BM, Larsen PV, Fedder J, de Silva PS, Larsen MD, Friedman S. Live birth and adverse birth outcomes in women with ulcerative colitis and Crohn's disease receiving assisted reproduction: a 20-year nationwide cohort study. Gut. 2016;65(5):767-776. doi:10.1136/gutjnl-2015-311246

13. Pabby V, Oza SS, Dodge LE, et al. In vitro fertilization is successful in women with ulcerative colitis and ileal pouch anal anastomosis. Am J Gastroenterol. 2015;110(6):792-797. doi:10.1038/ajg.2014.400

14. Norgard BM, Larsen MD, Friedman S, Knudsen T, Fedder J. Decreased chance of a live born child in women with rheumatoid arthritis after assisted reproduction treatment: a nationwide cohort study. Ann Rheum Dis. 2019;78(3):328-334. doi:10.1136/annrheumdis-2018-214619

15. Jolving LR, Larsen MD, Fedder J, Norgard BM. Live birth in women with multiple sclerosis receiving assisted reproduction. Reprod Biomed Online. 2020;40(5):711-718. doi:10.1016/j.rbmo.2020. 01.013

16. Larsen MD, Jolving LR, Fedder J, Norgard BM. The efficacy of assisted reproductive treatment in women with epilepsy. Reprod Biomed Online. 2020;41(6):1015-1022. doi:10.1016/j. rbmo.2020.07.019

17. Jolving LR, Larsen MD, Fedder J, Friedman S, Norgard BM. The chance of a live birth after assisted reproduction in women with thyroid disorders. Clin Epidemiol. 2019;11:683-694. doi:10.2147/ CLEP.S208574

18. Unuane D, Velkeniers B, Deridder S, Bravenboer B, Tournaye H, De Brucker M. Impact of thyroid autoimmunity on cumulative delivery rates in in vitro fertilization/intracytoplasmic sperm injection patients. Fertil Steril. 2016;106(1):144-150. doi:10.1016/j. fertnstert.2016.03.011

19. Chai J, Yeung WY, Lee CY, Li HW, Ho PC, Ng HY. Live birth rates following in vitro fertilization in women with thyroid autoimmunity and/or subclinical hypothyroidism. Clin Endocrinol (Oxf). 2014;80 (1):122-127. doi:10.1111/cen.12220

20. Larsen MD, Jensen DM, Fedder J, Jolving LR, Norgard BM. Liveborn children after assisted reproduction in women with type 1 diabetes and type 2 diabetes: a nationwide cohort study. Diabetologia. 2020;63(9):1736-1744. doi:10.1007/s00125-02005193-6

21. Diamond MP, Freeman ML. Clinical implications of postsurgical adhesions. Hum Reprod Update. 2001;7(6):567-576. doi:10.1093/ humupd/7.6.567

22. Mahadevan U. Fertility and pregnancy in the patient with inflammatory bowel disease. Gut. 2006;55(8):1198-1206. doi:10.1136/ gut.2005.078097

23. Johnson P, Richard C, Ravid A, et al. Female infertility after ileal pouch-anal anastomosis for ulcerative colitis. Dis Colon Rectum. 2004;47(7):1119-1126. doi:10.1007/s10350-004-0570-7

24. Ording Olsen K, Juul S, Berndtsson I, Oresland T, Laurberg S. Ulcerative colitis: female fecundity before diagnosis, during disease, and after surgery compared with a population sample. Gastroenterology. 2002;122(1):15-19. doi:10.1053/gast.2002.30345
25. Waljee A, Waljee J, Morris AM, Higgins PD. Threefold increased risk of infertility: a meta-analysis of infertility after ileal pouch anal anastomosis in ulcerative colitis. Gut. 2006;55(11):1575-1580. doi:10.1136/gut.2005.090316

26. Wikland M, Jansson I, Asztely M, et al. Gynaecological problems related to anatomical changes after conventional proctocolectomy and ileostomy. Int J Colorectal Dis. 1990;5(1):49-52. doi:10.1007/ BF00496151

27. Ban L, Tata LJ, Humes DJ, Fiaschi L, Card T. Decreased fertility rates in 9639 women diagnosed with inflammatory bowel disease: a United Kingdom population-based cohort study. Aliment Pharmacol Ther. 2015;42(7):855-866. doi:10.1111/apt.13354

28. Friedman S, Nielsen J, Nohr EA, Jolving LR, Norgard BM. Comparison of time to pregnancy in women with and without inflammatory bowel diseases. Clin Gastroenterol Hepatol. 2020;18 (7):1537-1544. doi:10.1016/j.cgh.2019.08.031

29. Freour T, Miossec C, Bach-Ngohou K, et al. Ovarian reserve in young women of reproductive age with Crohn's disease. Inflamm Bowel Dis. 2012;18(8):1515-1522. doi:10.1002/ibd.21872

30. Senates E, Colak Y, Erdem ED, et al. Serum anti-Mullerian hormone levels are lower in reproductive-age women with Crohn's disease compared to healthy control women. J Crohns Colitis. 2013;7(2): e29-34. doi:10.1016/j.crohns.2012.03.003

31. Norgard BM, Larsen MD, Friedman S, Fedder J. Corticosteroids prior to embryo transfer in assisted reproduction in women with crohn's disease and ulcerative colitis - A Nationwide Cohort Study. Clin Epidemiol. 2020;12:317-326. doi:10.2147/CLEP.S234996

32. Schmidt M, Schmidt SA, Sandegaard JL, Ehrenstein V, Pedersen L, Sorensen HT. The Danish National Patient Registry: a review of content, data quality, and research potential. Clin Epidemiol. 2015;7:449-490. doi:10.2147/CLEP.S91125

33. Schmidt M, Pedersen L, Sorensen HT. The Danish Civil Registration System as a tool in epidemiology. Eur J Epidemiol. 2014;29 (8):541-549. doi:10.1007/s10654-014-9930-3

34. Pottegard A, Schmidt SAJ, Wallach-Kildemoes H, Sorensen HT, Hallas J, Schmidt M. Data resource profile: the Danish National Prescription Registry. Int $J$ Epidemiol. 2017;46(3):798-798f. doi:10.1093/ije/dyw213

35. Wallenius M, Skomsvoll JF, Irgens LM, et al. Fertility in women with chronic inflammatory arthritides. Rheumatology (Oxford). 2011;50 (6):1162-1167. doi:10.1093/rheumatology/keq458

36. Jawaheer D, Zhu JL, Nohr EA, Olsen J. Time to pregnancy among women with rheumatoid arthritis. Arthritis Rheum. 2011;63 (6):1517-1521. doi:10.1002/art.30327

37. Poser S, Raun NE, Poser W. Age at onset, initial symptomatology and the course of multiple sclerosis. Acta Neurol Scand. 1982;66 (3):355-362. doi:10.1111/j.1600-0404.1982.tb06856.x

38. Love S. Demyelinating diseases. J Clin Pathol. 2006;59 (11):1151-1159. doi:10.1136/jcp.2005.031195

39. Cavalla $\mathrm{P}$, Rovei V, Masera $\mathrm{S}$, et al. Fertility in patients with multiple sclerosis: current knowledge and future perspectives. Neurol Sci. 2006;27(4):231-239. doi:10.1007/s10072-006-0676-x

40. McCombe PA, Stenager E. Female infertility and multiple sclerosis: is this an issue? Mult Scler. 2015;21(1):5-7. doi:10.1177/ 1352458514549406

41. Jalkanen A, Alanen A, Airas L; Finnish Multiple S, Pregnancy Study G. Pregnancy outcome in women with multiple sclerosis: results from a prospective nationwide study in Finland. Mult Scler. 2010;16 (8):950-955. doi:10.1177/1352458510372629

42. Moberg JY, Laursen B, Thygesen LC, Magyari M. Reproductive history of the Danish multiple sclerosis population: a register-based study. Mult Scler. 2020;26(8):902-911. doi:10.1177/1352458519851245

43. Michel L, Foucher Y, Vukusic S, et al. Increased risk of multiple sclerosis relapse after in vitro fertilisation. $J$ Neurol Neurosurg Psychiatry. 2012;83(8):796-802. doi:10.1136/jnnp-2012-302235 
44. Correale J, Farez MF, Ysrraelit MC. Increase in multiple sclerosis activity after assisted reproduction technology. Ann Neurol. 2012;72 (5):682-694. doi:10.1002/ana.23745

45. Hellwig K, Correale J. Artificial reproductive techniques in multiple sclerosis. Clin Immunol. 2013;149(2):219-224. doi:10.1016/j. clim.2013.02.001

46. Robertson SA, Jin M, Yu D, et al. Corticosteroid therapy in assisted reproduction - immune suppression is a faulty premise. Hum Reprod. 2016;31(10):2164-2173. doi:10.1093/humrep/dew186

47. Boomsma CM, Keay SD, Macklon NS. Peri-implantation glucocorticoid administration for assisted reproductive technology cycles. Cochrane Database Syst Rev. 2012;(6):CD005996. doi:10.1002/ 14651858.CD005996.pub3

48. de Vries EE, van den Munckhof B, Braun KP, van Royen-kerkhof A, de Jager W, Jansen FE. Inflammatory mediators in human epilepsy: a systematic review and meta-analysis. Neurosci Biobehav Rev. 2016;63:177-190. doi:10.1016/j.neubiorev.2016.02.007

49. Terrone G, Salamone A, Vezzani VA. Inflammation and epilepsy: preclinical findings and potential clinical translation. Curr Pharm Des. 2017;23(37):5569-5576. doi:10.2174/1381612823666170926113754

50. Rana A, Musto AE. The role of inflammation in the development of epilepsy. J Neuroinflammation. 2018;15(1):144. doi:10.1186/s12974018-1192-7

51. Lofgren E, Pouta A, von Wendt L, Tapanainen J, Isojarvi JI, Jarvelin MR. Epilepsy in the northern Finland birth cohort 1966 with special reference to fertility. Epilepsy Behav. 2009;14 (1):102-107. doi:10.1016/j.yebeh.2008.08.007

52. Farmen AH, Grundt JH, Tomson T, et al. Age-specific birth rates in women with epilepsy: a population-based study. Brain Behav. 2016;6 (8):e00492. doi:10.1002/brb3.492

53. Schupf N, Ottman R. Likelihood of pregnancy in individuals with idiopathic/cryptogenic epilepsy: social and biologic influences. Epilepsia. 1994;35(4):750-756. doi:10.1111/j.1528-1157.1994.tb02506.x

54. Crawford P, Hudson S. Understanding the information needs of women with epilepsy at different lifestages: results of the 'Ideal World' survey. Seizure. 2003;12(7):502-507. doi:10.1016/S1059-1311(03)00085-2

55. Korevaar TIM, Minguez-Alarcon L, Messerlian C, et al. Association of thyroid function and autoimmunity with ovarian reserve in women seeking infertility care. Thyroid. 2018;28(10):1349-1358. doi:10.1089/thy.2017.0582

56. Cho MK. Thyroid dysfunction and subfertility. Clin Exp Reprod Med. 2015;42(4):131-135. doi:10.5653/cerm.2015.42.4.131

57. Twig G, Shina A, Amital H, Shoenfeld Y. Pathogenesis of infertility and recurrent pregnancy loss in thyroid autoimmunity. J Autoimmun. 2012;38(2-3):J275-281. doi:10.1016/j.jaut.2011.11.014

58. Artini PG, Uccelli A, Papini F, et al. Infertility and pregnancy loss in euthyroid women with thyroid autoimmunity. Gynecol Endocrinol. 2013;29(1):36-41. doi:10.3109/09513590.2012.705391

59. Andersen SL, Olsen J, Laurberg P. Hypothyroidism and pregnancy loss: comparison with hyperthyroidism and diabetes in a Danish population-based study. Clin Endocrinol (Oxf). 2016;85(6):962-970. doi:10.1111/cen.13136

60. Cai Y, Zhong L, Guan J, et al. Outcome of in vitro fertilization in women with subclinical hypothyroidism. Reprod Biol Endocrinol. 2017;15(1):39. doi:10.1186/s12958-017-0257-2

61. Kim CH, Ahn JW, Kang SP, Kim SH, Chae HD, Kang BM. Effect of levothyroxine treatment on in vitro fertilization and pregnancy outcome in infertile women with subclinical hypothyroidism undergoing in vitro fertilization/intracytoplasmic sperm injection. Fertil Steril. 2011;95(5):1650-1654. doi:10.1016/j.fertnstert.2010.12.004

62. Unuane D, Velkeniers B, Bravenboer B, et al. Impact of thyroid autoimmunity in euthyroid women on live birth rate after IUI. Hum Reprod. 2017;32(4):915-922. doi:10.1093/humrep/dex033

63. De Leo S, Pearce EN. Autoimmune thyroid disease during pregnancy. Lancet Diabetes Endocrinol. 2018;6(7):575-586. doi:10.1016/S2213-8587(17)30402-3
64. Lukaszuk K, Kunicki M, Kulwikowska P, et al. The impact of the presence of antithyroid antibodies on pregnancy outcome following intracytoplasmatic sperm injection-ICSI and embryo transfer in women with normal thyreotropine levels. J Endocrinol Invest. 2015;38(12):1335-1343. doi:10.1007/s40618-015-0377-5

65. Tan S, Dieterle S, Pechlavanis S, Janssen OE, Fuhrer D. Thyroid autoantibodies per se do not impair intracytoplasmic sperm injection outcome in euthyroid healthy women. Eur J Endocrinol. 2014;170 (4):495-500. doi:10.1530/EJE-13-0790

66. Sakar MN, Unal A, Atay AE, et al. Is there an effect of thyroid autoimmunity on the outcomes of assisted reproduction? J Obstet Gynaecol. 2016;36(2):213-217. doi:10.3109/01443615.2015.1049253

67. Busnelli A, Paffoni A, Fedele L, Somigliana E. The impact of thyroid autoimmunity on IVF/ICSI outcome: a systematic review and meta-analysis. Hum Reprod Update. 2016;22(6):775-790. doi:10.1093/humupd/dmw019

68. Toulis KA, Goulis DG, Venetis CA, et al. Risk of spontaneous miscarriage in euthyroid women with thyroid autoimmunity undergoing IVF: a meta-analysis. Eur J Endocrinol. 2010;162(4):643-652. doi:10.1530/EJE-09-0850

69. van den Boogaard E, Vissenberg R, Land JA, et al. Significance of (sub)clinical thyroid dysfunction and thyroid autoimmunity before conception and in early pregnancy: a systematic review. Hum Reprod Update. 2011;17(5):605-619. doi:10.1093/humupd/dmr024

70. Askenasy N. Mechanisms of diabetic autoimmunity: i-the inductive interface between islets and the immune system at onset of inflammation. Immunol Res. 2016;64(2):360-368. doi:10.1007/s12026-015-8753-y

71. Askenasy N. Mechanisms of diabetic autoimmunity: II-Is diabetes a central or peripheral disorder of effector and regulatory cells? Immunol Res. 2016;64(1):36-43. doi:10.1007/s12026-015-8725-2

72. Clausen TD, Mathiesen E, Ekbom P, Hellmuth E, Mandrup-Poulsen T, Damm P. Poor pregnancy outcome in women with type 2 diabetes. Diabetes Care. 2005;28(2):323-328. doi:10.2337/diacare.28.2.323

73. Jensen DM, Ovesen P, Beck-Nielsen H, et al. Gestational weight gain and pregnancy outcomes in 481 obese glucose-tolerant women. Diabetes Care. 2005;28(9):2118-2122. doi:10.2337/diacare.28.9.2118

74. Peppard HR, Marfori J, Iuorno MJ, Nestler JE. Prevalence of polycystic ovary syndrome among premenopausal women with type 2 diabetes. Diabetes Care. 2001;24(6):1050-1052. doi:10.2337/ diacare.24.6.1050

75. Thong EP, Codner E, Laven JSE, Teede H. Diabetes: a metabolic and reproductive disorder in women. Lancet Diabetes Endocrinol. 2020;8 (2):134-149. doi:10.1016/S2213-8587(19)30345-6

76. Pinborg A, Gaarslev C, Hougaard CO, et al. Influence of female bodyweight on IVF outcome: a longitudinal multicentre cohort study of 487 infertile couples. Reprod Biomed Online. 2011;23 (4):490-499. doi:10.1016/j.rbmo.2011.06.010

77. Crawford G, Ray A, Gudi A, Shah A, Homburg R. The role of seminal plasma for improved outcomes during in vitro fertilization treatment: review of the literature and meta-analysis. Hum Reprod Update. 2015;21(2):275-284. doi:10.1093/humupd/dmu052

78. Simon C, Martin JC, Pellicer A. Paracrine regulators of implantation. Baillieres Best Pract Res Clin Obstet Gynaecol. 2000;14(5):815-826. doi:10.1053/beog.2000.0121

79. Diedrich K, Fauser BC, Devroey P, Griesinger G; Evian Annual Reproduction Workshop G. The role of the endometrium and embryo in human implantation. Hum Reprod Update. 2007;13(4):365-377. doi:10.1093/humupd/dmm011

80. Kushnir VA, Solouki S, Sarig-Meth T, et al. Systemic inflammation and autoimmunity in women with chronic endometritis. Am J Reprod Immunol. 2016;75(6):672-677. doi:10.1111/aji.12508

81. Vitagliano A, Noventa M, Gizzo S. Autoimmunity, systemic inflammation, and their correlation with repeated implantation failure and recurrent miscarriage: is chronic endometritis the missing piece of the jigsaw? Am J Reprod Immunol. 2017;77(1):e12597. doi:10.1111/ aji.12597 
82. Gupta SK, Malhotra SS, Malik A, Verma S, Chaudhary P. Cell signaling pathways involved during invasion and syncytialization of trophoblast cells. Am J Reprod Immunol. 2016;75(3):361-371. doi:10.1111/aji.12436

83. Kitaya K, Yasuo T, Tada Y, et al. Unusual inflammation in gynecologic pathology associated with defective endometrial receptivity. Histol Histopathol. 2014;29(9):1113-1127. doi:10.14670/HH29.1113

84. Weiss G, Goldsmith LT, Taylor RN, Bellet D, Taylor HS. Inflammation in reproductive disorders. Reprod Sci. 2009;16 (2):216-229. doi:10.1177/1933719108330087

85. McGonagle D, McDermott MF. A proposed classification of the immunological diseases. PLoS Med. 2006;3(8):e297. doi:10.1371/ journal.pmed.0030297

86. Arakelyan A, Nersisyan L, Poghosyan D, et al. Autoimmunity and autoinflammation: a systems view on signaling pathway dysregulation profiles. PLoS One. 2017;12(11):e0187572. doi:10.1371/journal. pone. 0187572

87. Croia C, Bursi R, Sutera D, Petrelli F, Alunno A, Puxeddu I. One year in review 2019: pathogenesis of rheumatoid arthritis. Clin Exp Rheumatol. 2019;37(3):347-357.

88. Roep BO. The role of T-cells in the pathogenesis of Type 1 diabetes: from cause to cure. Diabetologia. 2003;46(3):305-321. doi:10.1007/ s00125-003-1089-5

89. van der Spek AH, Fliers E, Boelen A. Thyroid hormone metabolism in innate immune cells. $J$ Endocrinol. 2017;232(2):R67-R81. doi:10.1530/JOE-16-0462

90. Liu S, Diao L, Huang C, Li Y, Zeng Y, Kwak-Kim JYH. The role of decidual immune cells on human pregnancy. J Reprod Immunol. 2017;124:44-53. doi:10.1016/j.jri.2017.10.045
91. Boomsma CM, Keay SD, Macklon NS. Peri-implantation glucocorticoid administration for assisted reproductive technology cycles. Cochrane Database Syst Rev. 2007;(1):CD005996.

92. Mor G, Cardenas I, Abrahams V, Guller S. Inflammation and pregnancy: the role of the immune system at the implantation site. Ann $N \quad Y \quad$ Acad Sci. 2011;1221(1):80-87. doi:10.1111/j.17496632.2010.05938.x

93. Massarotti C, Inglese M, Anserini P. Fertility in multiple sclerosis patients: still many unanswered questions. Reprod Biomed Online. 2020;41(3):567. doi:10.1016/j.rbmo.2020.06.003

94. Lass A, Weiser W, Munafo A, Loumaye E. Leukemia inhibitory factor in human reproduction. Fertil Steril. 2001;76(6):1091-1096. doi:10.1016/S0015-0282(01)02878-3

95. Pundir J, Pundir V, Omanwa K, Khalaf Y, El-Toukhy T. Hysteroscopy prior to the first IVF cycle: a systematic review and meta-analysis. Repro Biomed. 2014;28(2):151-161. doi:10.1016/j. rbmo.2013.09.025

96. Stewart CL, Kaspar P, Brunet LJ, et al. Blastocyst implantation depends on maternal expression of leukaemia inhibitory factor. Nature. 1992;359(6390):76-79. doi:10.1038/359076a0

97. Potdar N, Gelbaya T, Nardo LG. Endometrial injury to overcome recurrent embryo implantation failure: a systematic review and meta-analysis. Reprod Biomed Online. 2012;25(6):561-571. doi:10.1016/j.rbmo.2012.08.005

98. Liberati A, Altman D, Tetzlaff J, et al. The PRISMA statement for reporting systematic reviews and meta-analyses of studies that evaluate health care interventions: explanation and elaboration. Journal of Clinical Epidemiology. 2009;62(10).
Clinical Epidemiology

\section{Publish your work in this journal}

Clinical Epidemiology is an international, peer-reviewed, open access, online journal focusing on disease and drug epidemiology, identification of risk factors and screening procedures to develop optimal preventative initiatives and programs. Specific topics include: diagnosis, prognosis, treatment, screening, prevention, risk factor modification, systematic reviews, risk \& safety of medical interventions, epidemiology \& biostatistical methods, and evaluation of guidelines, translational medicine, health policies \& economic evaluations. The manuscript management system is completely online and includes a very quick and fair peer-review system, which is all easy to use.

\section{Dovepress}

